\title{
Wage inequality and the role of multinationals: Evidence from UK panel data
}

\author{
(Forthcoming in Labour Economics) \\ Karl Taylor ${ }^{1}$ and Nigel Driffield ${ }^{2}$ \\ ${ }^{1}$ Department of Economics, University of Leicester, \\ University Road, Leicester. LE1 7RH \\ 2Birmingham Business School, University of Birmingham, \\ Edgbaston, Birmingham. B15 2T'T
}

\begin{abstract}
Despite the increased attention on the impacts of globalisation, there has been little empirical investigation into the impact of multinational firms on the domestic labour market and in particular wage inequality, this is in spite of a rapid increase in FDI at around the same time of rising inequality. Using UK panel data this paper tests whether inward flows of FDI have contributed to increasing wage inequality. Even after controlling for the two most common explanations of wage inequality, technology and trade, we find that FDI has a significant effect upon wage inequality, with the overall impact of FDI explaining on average $11 \%$ of wage inequality.
\end{abstract}

Keywords: Wage inequality; FDI spillovers

JEL Classification: F21; F23; J31

We are grateful to the Office of National Statistics for supplying the primary data used herein and to the ESRC Data Archive for supply the SPRU (Science Policy Research Unit) innovations database. Thanks to participants at the International Economic Association conference on Globalisation and Labour Markets 2000, and for comments and suggestions from Mary Amiti, Sarah Brown, Gerry Makepeace, Alan Manning, Patrick Minford, Steve Thompson, three anonymous referees and the editor Alison Booth. For data access and coding contact Dr Karl Taylor by email: kbt3@le.ac.uk. 


\section{Introduction}

Over the past two decades a number of studies have documented the relative decline in unskilled wages for a number of countries (Bound and Johnson, 1992; Levy and Murnane, 1992; Machin, 1996; and Berman et al., 1998). Since the relative supply of unskilled workers has also declined in recent years, the trends in relative wages are seen as evidence of a shift away from unskilled workers caused by an increase in relative demand for higher skilled labour. This phenomenon has occurred within industries and narrowly defined skill groups in the UK and USA, Katz and Autor (1999). The two most common explanations behind such a demand shift are exogenous and endogenous technological change, biased in favour of skilled labour and growing international trade (Levy and Murnane, 1992; Gottschalk and Smeeding, 1997). There is some disagreement about whether exogenous technological advance or trade is the most important factor in causing increasing demand for skilled workers $^{1}$ (Machin and Van Reenen, 1998; Wood, 1994; and Desjonqueres et al., 1999), and this is as much a theoretical issue as an empirical one (Haskel, 2000; Slaughter, 1999). However, it is fair to say that the majority of research has focused upon trade and technological change as the main causes of changes in labour demand.

Both trade and the pace of technological change have arguably accelerated over the past two decades, however foreign direct investment (FDI) by multinational enterprises (MNEs) both into and out of the UK has also grown at a rapid rate in recent years, such that investment by foreign firms has accounted for approximately $20 \%$ of total net capital expenditure since 1987, Driffield (1999). This growth of foreign owned manufacturing has occurred at a time of rising UK wage inequality. Figure 1 shows the UK skilled wage share,

\footnotetext{
${ }^{1}$ This issue is often referred to as the "trade versus technology" debate.
} 
our measure of wage inequality, measured as the wage bill ratio defined as total average domestic sector annual wages of non-operatives (our measure of the skilled) to the average total domestic sector annual wages (operatives, the unskilled, plus non-operatives). ${ }^{2}$ Figure 1 also shows the share of foreign-owned affiliate employment in total UK manufacturing employment from 1983 to 1992 . The skilled wage share rose from a low of about $381 / 2 \%$ in 1984 to $43 \frac{1}{2} \%$ in 1992 . At the same time, foreign affiliate employment rose from a low of $103 / 4 \%$ in 1987 to about $15 \%$ by 1992 . These parallel trends between the skilled wage share and foreign employment shares show that multinational involvement in the UK economy occurred at a time of widening wage inequality, but says nothing about causality. We now discuss the mechanism by which multinational activity can affect wage inequality.

$$
<<\text { FIGURE } 1 \text { HERE }>>
$$

An important issue when seeking to link inward FDI to wage inequality, is the reported difference between foreign owned and domestic firms in a given location (or industry). Theoretically, this stems from the presumed firm specific advantage that an MNE must possess in order to succeed in an alien environment, see for example Vernon (1966) and Dunning (1979). More recently, this has been couched in terms of technological advantages, which generate productivity differences between foreign and domestic firms (Cantwell, 1991; Davies and Lyons, 1991; Griffith and Simpson, 2001; and Driffield and Taylor, 2001) and consequently differences in profitability between foreign and domestic firms, see Munday et al. (2003). There is growing evidence that in the UK this generates

\footnotetext{
${ }^{2}$ As with much previous research our data only allow us to distinguish between two groups of labour one interpreted as skilled (non-operatives) and the other unskilled (operatives). The disadvantage is that one may lose much information about the subtleties of the wage structure from this degree of aggregation - Katz and Autor (1999). However, Berman et al. (1994) and Machin and Van Reenen (1998) find that such aggregations do a reasonable job of matching a high/low educational breakdown in manufacturing.
} 
significant differences in terms of factor demand. Driffield (1996) finds that foreign firms pay wages above the industry average of around $7 \%$, partly due to productivity differences, Conyon et al. (2002) find a wage differential of $3.4 \%$, wholly attributable to productivity, whereas Girma et al. (2001) find wage and productivity differentials of 5\%. These studies suggest that foreign owned firms have different labour demand schedules from domestically owned firms.

Theoretical work to date has been based largely upon general equilibrium trade models with endowment driven comparative advantage, where the findings are mixed, variously suggesting that greater $\mathrm{MNE}$ activity can either raise or lower the skill mix (Feenstra and Hansen, 1997; Markusen, 1995; Markusen and Venables, 1998). For example, Feenstra and Hanson (1997) develop a North-South endowment driven model to examine the impact of FDI and find that it raises the skill premium in both regions. An alternative literature on the formation of MNEs is found in Markusen (1995) where the general equilibrium model starts out by maintaining that a MNEs distinguishing characteristic is their firm specific assets such as technology, marketing skills and management skills. Markusen and Venables (1998) use this type of approach to analyse the impact on relative wages in the parent and host country by MNE activity. In general, the overall impact upon wages depends upon the initial equilibrium and underlying parameter changes. Consequently the impact upon unskilled labour can be either positive or negative according to chosen specifications. It is such theoretical ambiguities that highlight the need for empirical work.

Figure 1 clearly shows that inward investment penetration has increased alongside wage inequality. The purpose of this paper is to extend this analysis, to examine the impact that FDI has on the demand for labour within the UK's domestic firms. The inference here is that foreign-owned firms demonstrate markedly different factor demand functions, from 
their domestic counterparts, and therefore entry by such firms is expected to impact on domestic labour markets as in Hubert and Pain (2001). Much of the work in the area linking FDI to inequality is concerned with comparing wages across countries, rather than focussing on the impacts of FDI upon the host country. Equally, much of the theoretical work is contradictory, as seen above, with the theoretical impact of FDI upon wage inequality remaining rather ambiguous. However, we anticipate two labour market effects from FDI.

The first effect we envisage is that foreign firms entering an industry will pay above the average for the industry, causing wages to be bid up in those sectors. Secondly, we anticipate an indirect effect, caused by the increase in technological capability associated with inward investment (one of the firm specific advantages mentioned by Markusen, 1995). It is hypothesised that a learning process will occur, in the manner suggested by Figini and Gorg (1999) and Barrell and Pain (1997). Barrell and Pain (1997) find that in the UK manufacturing sector that a $1 \%$ rise in the FDI stock is estimated to raise technical progress by $0.26 \%$. More recent estimates for the period 1983 to 1992 by Hubert and Pain (2001) find that a $1 \%$ rise in the total output of foreign owned firms raises technical progress by $1.05 \%$, implying that inward investment has yielded positive spillovers to domestic firms. The implied mechanism for this process is that technological advantages are transferred to domestic producers in the form of spillovers, Blomstrom (1989), Haddad and Harrison (1993) and Driffield (2001). It is this indirect effect which is of primary interest in that it will influence wage inequality within the domestic sector.

To our knowledge there has not been any systematic investigation into the impact of FDI upon growing UK wage inequality (Figini and Gorg, 1999, consider Ireland), and very few studies in the USA (Blonigen and Slaughter, 2001; Velde te, 2000). In response, this paper examines the impact of inward FDI upon relative wages in UK manufacturing 
industries at the 3 digit level over the period 1983 to 1992 - a period where wage inequality was at its most rampant (Machin, 1998).

\section{Empirical methodology}

Initially we carry out a decomposition analysis of the growth of the share of aggregate employment (wages) accounted for by skilled labour into between and within industry components. This approach follows Berman et al. (1994), Machin (1996) and Machin and Van Reenen (1998), although we are able to focus explicitly upon 3 digit industry data aggregated from domestic firms only (prior analysis includes domestic and foreign firm aggregates). The decomposition is important since if the increase in skill intensity is due to within industry shifts then the focus of the empirical analysis should be upon those factors capable of explaining within industry wage inequality. For example, Goux and Maurin (2000) offer an alternative explanation for increasing wage inequality, in the case of France, based on reduced demand for products made by firms employing large numbers of unskilled workers. However, by definition this is a between industry effect. Factors capable of explaining wage inequality occurring within industries are potentially skill biased technological change, outsourcing resulting from international trade and technology transfer through FDI. The basic formulation for the decomposition is as follows:

$$
\Delta P=\sum_{i} \Delta S_{i} \bar{P}_{i}+\sum_{i} \Delta P_{i} \bar{S}_{i}
$$

for $i=1 \ldots . . n$ industries, where $\Delta P$ represents the aggregate change in domestic employment shares for industry $i, S_{i}=L_{i} / L$ is industry $i$ 's share in total domestic manufacturing employment and $P_{i}=X_{i} / L_{i}$ is the share of domestic employment category $X$ (skilled labour) in total domestic manufacturing employment $(L)$. The first term represents aggregate 
employment changes due to changes in the share of employment between industries. The second term of equation 1 is the within industry component due to changes in the share of skilled labour (type X) within industries. Based upon existing evidence we would expect the majority of the skill changes to have occurred within industries and our empirical approach assumes this to be the case - the results of the decomposition backs this up (see Section IV).

To identify the link between inward FDI and within industry shifts in demand towards higher skilled labour, we exploit variations in FDI across manufacturing industries and between years. The theoretical framework is based upon a flexible translog cost function and follows the approach of Berman et al. (1994), where industry, $i$, costs are given as

$$
\ln C_{i}=f\left(W_{j}, W_{l}, K, Y, \boldsymbol{T}\right)_{i}
$$

where $C$ represents variable costs, $W$ is the price of variable factors $j$ and $l, K$ is the capital stock, $Y$ is output and the vector $\boldsymbol{T}$ represents other possible influences (such as technology). Given homogeneous costs of degree one in prices then normalising on one of the factor prices and applying Shepard's lemma two factor shares can be derived as:

$$
S_{i ₹}=\alpha_{z}+\delta_{K z} \ln K_{i}+\delta_{Y z} \ln Y_{i}+\gamma \ln \left(W_{j} / W_{l}\right)+\phi_{T z} \ln \boldsymbol{T}_{i} \quad z=j, l
$$

In our empirical investigation the two variable factors $j$ and $l$ are unskilled and skilled workers respectively. The following is estimated as an initial benchmark to consider the impact of technology on the wage bill share adopting an approach similar to Machin (1996):

$$
S W_{i t}=\left[\frac{W_{\text {skilled }}}{\left(W_{\text {skilled }}+W_{\text {unskilled }}\right)}\right]_{i t}=\Omega+\alpha \ln K_{i t}+\beta \ln Y_{i t}+\rho \ln (\mathrm{R} \nLeftarrow D / Y)_{i t-1}+\lambda \text { Time }+\varepsilon_{i t}
$$

where $S W$ is the share of the wage bill of higher skilled labour (here our definition of skill relies upon the distinction between operatives and non-operatives), R\&D stock is our 
measure of technological change, ${ }^{3}$ Time is a vector of time dummies, and $\Omega$ is a constant. Note that we drop the relative wage rate for the two types of labour $\left(W_{j} / W_{l}\right)$ due to the possible introduction of bias into the estimates as these terms are directly involved in the construction of the dependent variable, this is consistent with other work (Berman et al., 1994; Machin, 1996; Haskel and Heden, 1999). One solution, which has been widely used in the literature is to argue that time dummies will capture variation in wages and so we include these instead of the relative wage terms, see Chennells and Van Reenen (1999). Estimating equation 4 as a benchmark should yield results similar to Machin (1996), where technological change has a positive impact upon wage inequality and so is skill biased. To consider the role of FDI upon wage inequality we control not only for technological change but also the impact of trade, ${ }^{4}$ proxied by import and export intensity, so the wage bill share becomes:

$$
\begin{gathered}
S W_{i t}=\Omega+\alpha \ln K_{i t}+\beta \ln Y_{i t}+\rho \ln (\mathrm{R} \otimes D / Y)_{i t-1}+\pi \ln (\operatorname{Imports} / Y)_{i t} \\
+\operatorname{\theta ln}(\text { Exports } / Y)_{i t}+\psi \ln \mathrm{FDI} I_{i t}+\lambda \text { Time }+\varepsilon_{i t}
\end{gathered}
$$

Feenstra and Hanson (1995, 1996), Machin and Van Reenen (1998), and Blonigen and Slaughter (2001) justify the inclusion of other possible demand shifters, in the vector $\boldsymbol{T}$ (equations 2 and 3), such as technology and trade, by arguing that merely including the factors derived from theory will not capture other influences which could effect a firms

\footnotetext{
${ }^{3}$ Having a measure of the stock of $\mathrm{R} \& \mathrm{D}$ allows us to estimate in levels and first differences, rather than entering R\&D expenditure (a flow) in levels into a differenced equation, Aguirregabiria and Alonso-Borrego (2001). The proposed relationship between R\&D intensity and wage inequality is investigated with a lag structure. For example, the interpretation of a significant contemporaneous relation between $R \& D$ intensity and wage inequality is ambiguous. This is because it is anticipated that high R\&D activities involve the employment of high quality (relatively more skilled) workers (Katz and Autor, 1999). Moreover, Machin and Van Reenen (1998) find that lagged R\&D expenditures are associated with skill biased technological changes, and so we include the R\&D variable as a one year lag in all specifications.

${ }^{4}$ Note that our approach of adopting a translog cost function is a partial equilibrium model and as such doesn't do full justice to the international trade argument, Wood (1994). However, import intensity is widely used as a proxy for international trade in the labour economics literature.
} 
demand function. In a similar vein we also justify the inclusion of FDI in the wage bill share equation. Theoretically, we would expect the following signs $\partial S W_{i t} / \partial(R \& D / Y)_{i t-1}>0$ implying skill biased technological change, although it is possible for $\partial S W_{i t} / \partial(R \& D / Y)_{i t-1}<0$ that is low skill technology bias or for skill neutral bias $\partial S W_{i t} / \partial(R \& D / Y)_{i t-1}=0$. Whether outsourcing actually leads to wage inequality will depend upon what is outsourced i.e. high skill or low skill production activities. However, we would expect outsourcing to include a higher proportion of unskilled production activities, Wood (1994). Given this outsourcing should also lead to an increase in wage inequality and so $\partial S W_{i t} / \partial(\text { Imports } / Y)_{i t}>0$. Considering the role of exports upon wage inequality Bernard and Jensen (1997) found that increased exports in US plants were strongly associated with both between and within group wage inequality changes, hence $\partial S W_{i t} / \partial(\text { Exports } / Y)_{i t}>0$. However, Machin and Van Reenen (1998) could find no role for exports in explaining wage inequality change across OECD countries, so $\partial S W_{i t} / \partial(\text { Exports } / Y)_{i t}=0$. Given the lack of empirical evidence upon the role of exports in influencing wage inequality we would tentatively expect, that if significant, the impact should be positive. If FDI is considered to only have an impact upon productivity then the impact is ambiguous and will depend upon the distribution of skilled and unskilled labour across industries, however if FDI involves technological transfer from foreign to domestic firms then $\partial S W_{i t} / \partial(F D I)_{i t}>0 .^{5}$

The impact of trade, technology changes and especially technology diffusion through FDI may involve time lags - this is something which most of the work in the area has not

\footnotetext{
${ }^{5}$ Note that technology, trade and FDI can be considered to be aspects of globalisation. Moreover, although it is common in the literature to distinguish between technology and trade effects, Berman, Bound and Machin (1998), it is possible that the trade variables could be accounting for the importation of new capital equipment i.e. technology. Furthermore, in a Coe and Helpman (1995) model trade is a means to the adoption of R\&D undertaken in other countries.
} 
been able to get to grips with due to inadequate panel data. Because our data is over a long period of time and is a rich panel we propose to estimate the following:

$$
\begin{gathered}
S W_{i t}=\Omega_{1}+\alpha_{1} \ln K_{i t}+\beta_{1} \ln Y_{i t}+\rho_{1} \ln (\mathrm{R} \Theta D / Y)_{i t-1}+\pi_{1} \ln (\operatorname{Imports} / Y)_{i t}+ \\
\theta_{1} \ln (\text { Exports } / Y)_{i t}+\sum_{\tau=0} \psi_{1 \tau} \ln F D I_{i t-\tau}+\lambda_{1} \text { Time }+\Theta_{1} \boldsymbol{M}_{i t}+v_{1 i t} \equiv \Phi_{1} \boldsymbol{H}_{1}+v_{1 i t} \\
\equiv \Phi_{1} \boldsymbol{H}_{1}+v_{1 i t}
\end{gathered}
$$

and

$$
\begin{gathered}
S W_{i t}=\Omega_{2}+\alpha_{2} \ln K_{i t}+\beta_{2} \ln Y_{i t}+\rho_{2} \ln (\mathrm{R} \otimes D / Y)_{i t-1}+\pi_{2} \ln (\text { Imports } / Y)_{i t}+ \\
\theta_{2} \ln (\text { Exports } / Y)_{i t}+\psi_{21} \ln F D I_{i t}+\psi_{22} \ln \mathrm{FDI}_{i t}^{2}+\lambda_{2} \text { Time }+\Theta_{2} \boldsymbol{M}_{i t}+v_{2 i t} \\
\equiv \Phi_{2} \boldsymbol{H}_{2}+v_{2 i t}
\end{gathered}
$$

Where equations 6 and 6 ' are estimated in levels with $v_{1 i t}=\phi_{1 i}+\omega_{1 i t}, v_{2 i t}=\phi_{2 i}+\omega_{2 i t}$ and in each equation $\phi_{i}$ denotes unobservable industry specific effects, with $\omega_{i t}$ being the remainder of the disturbance. We also provide difference estimates of equations 6 and 6', so

$$
S W_{i t}=\gamma_{1} S W_{i t-1}+\Psi_{1} \Delta \boldsymbol{H}_{1}+\omega_{1 i t}
$$

and

$$
S W_{i t}=\gamma_{2} S W_{i t-1}+\Psi_{2} \Delta \boldsymbol{H}_{2}+\omega_{2 i t}
$$

based upon Generalised Methods of Moments (GMM) instrumental variables estimator, Arellano and Bond (1991), to control for endogeneity bias and unobserved industry effects. ${ }^{6}$

\footnotetext{
${ }^{6}$ There are advantages and disadvantages to estimating in levels. Much of the literature has sought to explain fluctuations in wage shares by analysing data that has been first differenced or detrended. In the case of panel data an approach often adopted to control for unobserved time invariant industry fixed effects is to first difference data. However, this type of analysis removes the trend component, where clearly the long term persistent movement of the trend in relative wages is of importance. By first differencing data researchers are only analysing year-to-year growth rates (Borjas and Ramey, 1994). Furthermore, estimating in levels allows an increase in a variable to influence the dependent variable in subsequent periods, this is reasonable if the effects are felt gradually over time - which is quite likely in the case of technology, trade and FDI spillovers. As stated above we also estimate
} 
The vector $\boldsymbol{M}$ contains other possible influences upon the wage gap for example a measure of industry concentration (where industries with larger firm size may have higher wages due to the employer-size wage effect, Green et al., 1996), and regional controls (Duranton and Monastiriotis, 2002). The interpretation of industry concentration is that it merely controls for the possibility of firms with market power paying higher wages, and therefore attracting a larger proportion of skilled workers. There is a large literature linking wage rates to product market power, see for example Stewart (1990). Given the above empirical model we can investigate (1) the impact that inward FDI has on the wage bill share, and (2) whether inward FDI has a greater impact upon the wage bill share than R\&D or trade.

To interpret FDI as a route of technological change through a learning process we would expect the following from equation $6: \psi_{1 Q} \geq \cdots \psi_{11} \geq \psi_{10}$ and $\partial^{2} \psi_{1 z} / \partial t^{2}<0$ where $z=0 \ldots Q$, that is the FDI coefficient should increase in size over time as technology is transferred but at a decreasing rate. This is a different interpretation of FDI upon wage bill shares from Figini and Gorg (1999) where the impact of FDI was proposed as a quadratic in a single year. We also provide estimates based upon the quadratic specification given in equation 6'. This empirical approach is based upon a model developed by Aghion and Howitt (1998) in which the introduction of new technologies leads to increasing demand for skilled labour and therefore increasing wage inequality. The Aghion and Howitt (1998) model shows that wage inequality first increases but at a decreasing rate after the introduction of new technologies due to a learning process. Hence from equation 6' we

equations 6 and 6 ' in first differences, by Generalised Method of Moments (GMM), as is common in the literature (Berman et al., 1994, 1998; and Machin and Van Reenen, 1998). GMM estimation also allows for a dynamic partial adjustment process, controls for potential endogeneity of variables, unobservable effects, and possible unit roots if the data is I(1). 
would expect $\psi_{21}>0$ and $\psi_{22}<0$. Whether learning takes place over time or the impacts of FDI are assimilated quickly, as well as determining the specification which best supports learning i.e. time lags versus a quadratic, can be tested by estimating equations 6,6 ' in levels and 6", 6" in differences.

\section{Data}

The data used are based at the 3-digit industry level for UK manufacturing sectors (SIC, 1980 sectors 2-4) over the period 1983 to 1992. This provides 101 industries over 10 years giving 1010 observations. All data are converted into natural logarithms and deflated to 1980 prices. Most of the data used in this study are published in The Annual Production Inquiry, formerly Report on the Census of Production, UK Office of National Statistics (ONS), for various years. The ONS provided data relating to the foreign owned sector of manufacturing at the 3-digit level. Our measure of unskilled workers (operatives) includes all manual wage earners i.e. those engaged in outside work of erecting, fitting etc., inspectors, maintenance workers and cleaners. Staff engaged in transport (including roundsmen) and employed in warehouses, stores, shops and canteens are also included in the definition.

The measure of technological change - research and development (R\&D) was taken from Business Monitors MO14, some data at the product level were provided directly by the ONS, and taken from various ONS Bulletins, facilitating the generation of a full series of R\&D stock data from 1984 onwards. ${ }^{7}$ Our initial measure of R\&D stock is calculated by summing over the previous 3 years expenditure (RDE), discounted by 10\% per annum, so:

\footnotetext{
${ }^{7}$ Following this process, some 70 observations across various industries (out of a total of 1010 observations) were missing, so some interpolation was necessary. Data are not available to distinguish between foreign and domestically owned R\&D. However, data for the latter part of the period indicate that even by 1989, under $10 \%$ of all manufacturing R\&D in the UK was funded by foreign firms, MO14, 1989.
} 


$$
\operatorname{RDSTOCK}_{i, 1983}=\left(0.9 \times \mathrm{RDE}_{i, 1982}\right)+\left(0.81 \times \mathrm{RDE}_{i, 1981}\right)+\left(0.729 \times \mathrm{RDE}_{i, 1980}\right)
$$

Subsequent to this the series was calculated as:

$$
\operatorname{RDSTOCK}_{i t}=\left(0.9 \times \operatorname{RDSTOCK}_{i t-1}\right)+\mathrm{RDE}_{i t-1}
$$

The stock of R\&D is then weighted by value added, to obtain a measure of intensity.

We also have a second measure of technological change, given as an innovations count which comes from the SPRU (Science Policy Research Unit) innovations database. Innovations are defined as "the successful commercial introduction of new or improved products, processes and materials introduced in Britain" over the period 1943-83. ${ }^{8,9}$ The innovations data are used to test the robustness of the results, particularly to investigate whether any significant impacts found from FDI are biased, because FDI may be attracted towards industries which have made recent innovative discoveries. The measure of innovation used is the two digit cumulative stock of major innovations used between 1973 and 1982 . We match at the two digit level since the SPRU database uses SIC industry codes pre 1980 classifications and so it is not possible to accurately match to the three digit level.

Industry level data on capital expenditure are available from 1975 onwards, although of course there was a SIC break in 1980. Data from 1975-1979, at the 4 and 5 digit level (based on the previous classification) were used to generate initial values of the capital stock for the 3 digit level for the new (1980) classification, based on:

$$
K_{i t}=\left(0.9 \times K_{i t-1}\right)+I_{i t-1}
$$

where $I$ is investment. This provides a starting value of $K_{i, 1980}$ from which data from 1980

\footnotetext{
8 Obviously the SPRU data only overlaps our dataset by a single year (unfortunately the data end in 1983) and we describe how we implement the control in the empirical analysis in section IV.

${ }^{9}$ Machin (1996) describes the SPRU data in greater detail.
} 
onwards published in the census of production can be used to generate the full series in the same manner for 1983 onwards depreciated at a rate of 10\% per annum.

Import and export data are provided in Business Monitors and are weighted by industry value added to gain a measure of their intensity. ${ }^{10}$ Table 1 , below, defines the variables used in the empirical analysis and Table 2, below, shows summary statistics of the data in both levels and first differences.

\section{$<<$ TABLES 1 AND 2 HERE $>>$}

$\mathrm{R} \& \mathrm{D}$ intensity was around $6 \%$ in 1983 , above the period average (Table 2), although declined from the late 1980s into the 1990 s to around $4.5 \%$ and is consistent with other findings (Machin and Van Reenen, 1998). Import intensity increased over time from a low of $40 \%$ to above the period average of $46 \%$ (Table 2 ) by the late 1980s (consistent with OECD STAN data). Export intensity remained fairly steady over time, at around the period average, being equal to 32\% in 1983 and 31\% in 1991 just dipping slightly in the late 1980s. We have two measures of FDI impacts - one based upon employment shares (as used by Figini and Gorg, 1999; Blonigen and Slaughter, 2001; and Girma et al., 2001) and the other upon capital expenditure. The FDI measure based upon the share of FDI net capital expenditure shows similar trends to the employment measure (Figure 1) rising from $16 \%$ of total net capital expenditure in 1984 to some 22\% by 1992 . Over the period FDI accounts for around 16\% of total employment and $22 \%$ of the total capital expenditure (note Table 2 shows unweighted FDI data). Both these measures of FDI are used in the empirical analysis.

A natural question to ask is whether the presence of FDI is concentrated in just a few sectors or more evenly across industries. For instance, a positive association between

\footnotetext{
${ }^{10}$ Neither import nor export data distinguish between purchases made by foreign and domestic firms in the UK.
} 
FDI and the skilled wage bill share, in the levels equations 6, 6' or first differences 6", 6"', may just reflect that FDI is located in a few high productivity sectors. Table A1 in the Appendix shows FDI across 3 digit industries over the period 1983 to 1992. Clearly, based upon either the employment definition or the capital definition of FDI shares it is clear that foreign firms are located across many manufacturing sectors not just a couple. Although over the period some sectors have no foreign presence, for example: structural clay products (sic241); asbestos goods (sic244); manufacture of cycles and motor cycles (sic363) etc., many sectors have a large foreign presence. In particular, the four industries with the largest FDI shares (greater than 40\% employment and greater than 50\% capital shares) are: other electronic equipment (sic345); manufacture of office machinery and data processing equipment (sic330); agriculture, machinery \& tractors (sic321); motor vehicles \& their engines (sic351); and specialised chemical products mainly for household \& office use (sic259). The idea that there may be a role for FDI in explaining the skilled wage bill share is borne out by a positive correlation over time between the two, see Figure 2 for the employment share definition of FDI (a similar picture emerges from the capital definition of FDI). Any possible association between FDI and wage inequality within industries is investigated further in Section IV.

$$
<<\text { FIGURE } 2 \text { HERE }>>
$$

\section{Empirical results}

Before implementing the econometric analysis to consider the role of FDI upon wage inequality further we initially decompose the change in both skilled employment and wages into between and within industry components based upon equation 1 . The literature, which has examined wage inequality to date, has unanimously found skill upgrading to have 
occurred within industries rather than between. In carrying out our decompositions we focus explicitly upon the skilled employment and wage changes experienced by the domestic sector alone (by default the existing literature considers both domestic and foreign owned sector outcomes). The results of the decomposition are shown below in Table 3. Clearly, the majority of changes in employment and wages, moving towards skilled labour, occurred within industries, with similar magnitudes to those described by Machin (1996) over the period 1979 to 1990. Having found skill changes (upgrading) having occurred within industries, the following analysis looks to consider what factors can potentially explain the increase of wage inequality within industries. ${ }^{11}$

$$
<<\text { TABLE } 3 \text { HERE }>>
$$

Before we start the estimation we initially consider whether the data is stationary, since non stationarity in the data could result in spurious correlations. To do this in a panel setting the following regression is employed, based upon Levin and Lin (1992), where a time trend, $t$, individual, $\alpha_{i}$, and time, $\theta_{t}$, specific effects are incorporated into the unit root test based upon various specifications, the most general being:

$$
\Delta y_{i t}=\rho y_{i t-1}+\alpha_{0}+\delta t+\alpha_{i}+\theta_{t}+\varepsilon_{i t}
$$

A test for unit roots in the variable $y_{i t}$, where non stationarity is the null hypothesis, would be $H_{0}: \rho=0 \quad H_{1}: \rho<0$. The results are shown in Table 4 below based upon five variants of the most general specification, given in equation 10 , where there is clear evidence that the data are stationary, that is the null hypothesis is rejected unanimously. Perhaps given that there are only ten years of time series this is not surprising and a longer time series span of

${ }^{11}$ Rather than focusing upon factors able to explain between industry shifts, such as structural demand changes, which are important in the case of France, see Goux and Maurin (2000). 
data may yield different conclusions. However, based upon the results of Table 4 in what follows we treat the data as stationary. ${ }^{12}$

Initially, the data are used to assess the impact of technology upon the wage bill share estimating initially in levels by fixed effects, based upon various specifications of equations 6 and 6'. To control for the possible endogeneity of both value added and capital, since both are arguably determined simultaneously with labour demand, we lag both variables when estimating in levels (note that we also experimented with longer lags but the results were largely unaffected). This is a common approach for dealing with endogeneity when estimating translog cost functions where it is difficult to find convincing instruments. For example, Machin and Van Reenen (1998) and Caroli and Van Reenen (2001) lag technology and occupational indicators to attempt to mitigate endogeneity problems. When we carry out our differenced analysis we provide instruments for all endogenous variables as discussed below.

For all of the subsequent analysis the industry data was weighted by the 3 digit industry share of the total manufacturing wage bill. This essentially means that domestic wage inequality is aggregated to within industry wage inequality, which is where the majority of UK wage inequality has occurred, see above. In order to separate the proposed productivity "batting average" and spillover effects from foreign entry (see above) we restrict the data to industry variables derived from domestically owned firms. Consequently any impact from the FDI variable will be due to spillover effects rather than productivity differences between the domestic and foreign owned sector (productivity differentials are

\footnotetext{
12 We also implemented a test based upon Im, Pesaran and Shin (1997) where $\rho$ is allowed to vary across industries so the assumption that $\rho_{1}=\rho_{2}=\cdots=\rho_{N}=\rho$ is relaxed. Thus in equation 10 we substitute $\rho$ for $\rho_{i}$ where $i$ is an industry. The results of this approach were consistent with the findings from the Levin and Lin test implying stationarity and so are omitted for brevity.
} 
well documented in the UK, see section I, and so we want to focus explicitly on the impact of the indirect FDI technology spillover effects upon wage inequality which have not been investigated in the UK). The results in levels are shown in Table 5, below, and the first column of Table 5, based upon our baseline specification equation 4, suggests that technological change has a significant impact upon wage inequality and is biased towards skilled labour, which is consistent with previous findings (Machin, 1996). The second column shows the impact of trade (defined as import intensity) upon wage inequality, and is consistent with our a priori expectations as well as being statistically significant. Similarly, the third column considers the impact of trade defined by export intensity where again the impact is positive, consistent with Bernard and Jensen (1997).

Interestingly, moving to the fourth column, the impact of import intensity is larger than that of technology (although export intensity is now insignificant), and significantly so at the $5 \%$ level $\mathrm{F}(1,793)=6.14$, thus supporting some recent findings (Wood, 1994; and Anderton and Brenton, 1999). In the fifth column we look at the impact of FDI upon wage inequality. The impact is positive as expected although rather small. Introducing all three possible demand shifters in column 6 demonstrates that the impact of technology is significantly skill biased, although less so than trade (defined by import intensity) in magnitude. Both effects are larger than the impact of FDI upon wage inequality. There is no role for trade effects operating through export intensity and the estimated coefficient upon FDI is not sensitive to its exclusion. The seventh column replicates column 6 by using our second definition of FDI based upon foreign net capital expenditure shares. Again the impact of FDI is significant and of similar magnitude to that found in the fifth column, although not as great as the effects of technology or trade.

$$
<<\text { TABLE } 5 \text { HERE }>>
$$


To consider whether FDI involves a learning effect whereby the domestic sector assimilates knowledge over time, in Panel B of Table 5, we introduce time lags on the FDI variables and also consider quadratic effects akin to Figini and Gorg (1999). Initially in column 8 we introduce a time lag into the specification, where FDI is defined by employment shares. Similarly, the ninth column gives the same specification but for FDI defined by net capital share. Neither of the specifications provide support for the hypothesis that the FDI effects are sustained over more than one year, while lags of higher order were also insignificant (not shown for brevity). In the tenth and eleventh columns we investigate whether FDI has a quadratic effect upon wage inequality. Some evidence is found in favour of this in column 10 for the employment share definition of FDI. This suggests that learning takes place quickly soon after the foreign firm enters the market and is consistent with the findings of Figini and Gorg (1999), suggesting that FDI increases wage inequality but at a decreasing rate over time.

The final columns of Table 5 Panel B consider the robustness of FDI coefficient and its interpretation further. For instance, FDI can still have a non-causal interpretation upon domestic wage inequality if multinational companies seek out industries, which have skill upgrading potential due to recent innovative discoveries. This may indeed bias the results so far reported. ${ }^{13}$ To deal with this a control is added to the empirical specification for the number of successful innovations used in each industry in the prior decade. ${ }^{14}$ We are able to control for whether FDI is attracted to industries which have made recent innovative discoveries by matching the SPRU data to each industry. Recent innovations are defined as having occurred in the decade prior to the current year. The results from including the

\footnotetext{
${ }^{13}$ We are grateful to an anonymous referee for pointing this out.

${ }^{14}$ The SPRU also contains information on innovations produced. Using this count as a control led to similar results with the FDI coefficient remaining robust.
} 
innovation count in the empirical analysis are shown in columns 12 and 13 of Table 5 Panel B. Both columns 12 and 13 are based upon the quadratic impacts of FDI, defined by employment and capital expenditure respectively, including the recent innovations count. In both specifications the coefficients and significance of the FDI quadratic hardly changes in respect to columns 9 and 10 , and the innovations count is small but significant. ${ }^{15}$ In other words, although FDI may be attracted to industries which have made recent innovative discoveries, perhaps to exploit technology or because of skill upgrading potential, there is no evidence that the results so far reported of the impact of FDI upon wage inequality are biased because of this.

To check the robustness of our results we also considered versions of equations 6 and 6' in first differences, given by equations 6" and 6"' estimated by Generalised Method of Moments, with the results shown in Table 6. This method also allows us to control for endogeneity effects, through instrumentation, and unobservable influences. In general if the residuals follow an $\operatorname{MA}(q)$ process then lagged independent variables of order $t-2-q$ will be valid instruments. In practice we have instrumented all strictly exogenous variables (industry specific) as well as the lagged values of predetermined variables from $t-2$ to $t-2-q$. In order to test the validity of the instruments a Sargan test for over-identifying restrictions is used, and we provide a test of second order serial correlation in the residual. This approach for dealing with potential endogeneity of variables in factor demand functions follows Aguirregabiria and Alonso-Borrego (2001). Table 6 is arranged in the same format as Table 5, with columns corresponding to exactly the same specifications, except that in Table 6 the data is differenced. The first five columns are wholly consistent with the estimation in levels.

\footnotetext{
${ }_{15}$ We also experimented with expanding the innovations horizon beyond a decade and the results were unaffected. Interacting the FDI variable with the innovations count yielded an insignificant coefficient with the estimates in the quadratic largely unchanged.
} 
Technology appears to be biased towards skilled labour but is outweighed by the importance of trade effects stemming from import intensity, column 4. FDI impacts are significant and positive under both the employment share definition (column 6) and the capital share definition (column 7), as found above, but are small in comparison to other aspects of globalisation.

$$
<<\text { TABLE } 6 \text { HERE }>>
$$

Panel B of Table 6 considers whether any learning effects take place through FDI specified either as time lags or a quadratic. The results mirror those of Table 5 in that there is no evidence of FDI having effects over time (again higher order lags were also insignificant). For example, in column 8 , based upon the employment share definition of FDI, there is a positive and significant impact in year $t$ a coefficient of 0.007 (2.25) yet lagged by one year the impact is insignificant 0.004 (1.01). The effect of FDI is again best specified as a quadratic as evident from columns 10 and 11, suggesting that assimilation of technology is speedy. These results confirm our estimates in Table 5 based upon levels in that FDI has an effect upon wage inequality, ${ }^{16}$ there is no evidence that this grows over time so any spillovers appear to be assimilated quickly by the domestic sector. The final two columns of Table 6 consider whether FDI can still have a non-causal interpretation even after controlling for R\&D, replicating the levels analysis of Table 5. Specifically, recent innovation counts by industry are added to the quadratic specification. Columns 12 and 13 report the results based upon the employment and capital definitions of FDI respectively. Under both specifications,

\footnotetext{
16 As a further robustness check equations 6 and 6' were estimated in differences over time as a pooled cross sectional equation using GLS to control for heteroscedasticity. The coefficients upon the FDI terms hardly changed and remained significant when dummies were included for the 10 industries with the largest employment (capital) shares, defined from the appendix. This suggests that the impact of FDI is not driven by its location in a few sectors and backs up the descriptive data in section III. Details of the estimates are available from the authors upon request.
} 
after including the innovation count, which is insignificant, the coefficients upon FDI are unaffected, consistent with the levels results reported above, implying that the FDI coefficients do have a causal interpretation. The Arellano and Bond test of second order serial correlation provides strong evidence in favour of the specifications adopted and is supported by the Sargan test of instrument validity which cannot reject the over identifying restrictions in all the estimates at the $1 \%$ level [critical value $\chi^{2}(35)=57.34$ ], with probabilities shown in square brackets.

So far we have seen how FDI has had a significant impact upon wage inequality which we interpret as domestic firms assimilating new technologies which are biased in favour of higher skilled labour. Finally, from the elasticities associated with technology, trade and FDI under our preferred specifications, given in Tables 5 and 6 as columns 12 and 13, we derive the percentage of wage inequality explained by each factor. Changes in the skilled wage bill share due to globalisation (which could be FDI, technology or trade) are given by:

$$
\partial S W=(\hat{\ell} \times \partial \text { Globalisation }) \times\left[\left(W_{s} \div\left(W_{s}+W_{u}\right)\right) \div \text { Globalisation }\right]
$$

where $\hat{\ell}$ is the estimated elasticity associated with either technology, trade or FDI. Results are shown in Table 7 for each definition of FDI and reveal that the actual change in inequality accounted for over the period by FDI is less than either trade or technology explaining at most around $14 \%$ of wage inequality. Table 7 also shows the impacts of other forms of globalisation namely trade and technology. Based upon the levels specification the $<<$ TABLE 7 HERE $>>$

impact of trade is twice as great as technology - over 50\% compared to $25 \%$, although under the differenced analysis the margin is smaller. The total effect of globalisation upon 
explaining the increase in wage inequality over time is extremely large under each specification - at best nearly all of the change can be explained by globalisation.

\section{Conclusions}

We find that FDI has a significant impact upon wage inequality, even after controlling for the two most common explanations of wage inequality - technology and trade. Governments have provided incentives to multinational corporations to attract inward investment, presumably because they believe that there is some kind of spillover effect from FDI which benefits the domestic market. However, despite evidence of such spillover effects, in terms of productivity and wages, along with the benefits of FDI recent evidence, Figini and Gorg (1999), has found that FDI actually led to increasing wage inequality. We also find that FDI activity has some undesirable affects upon the labour market, explaining on average (across FDI definitions and specifications) 11\% of wage inequality over the period. As far as we are aware these results are the first to investigate the impact of foreign firms upon the UK wage inequality and to benefit from the use panel data to control for fixed effects over time.

\section{References}

Aghion, P. and Howitt, P. (1998) Endogenous Growth Theory. Cambridge, MA: MIT Press. Aguirregabiria, V. and Alonso-Borrego, C. (2001) Occupational structure, technological innovation, and reorganization of production. Labour Economics, 8, 43-73.

Anderton, B. and Brenton, P. (1999) Outsourcing and low skilled workers in the UK. Bulletin of Economic Research, 51, 267-85.

Arellano, M. and Bond, S. (1991) Some tests of specification for panel data: Monte Carlo evidence and an application to employment equations. Review of Economic Studies, 58, 277-97. 
Barrell, R. and Pain, N. (1997) Foreign direct investment, technological change and economic growth within Europe. Economic Journal, 107, 1770-86.

Berman, E., Bound, J. and Griliches, Z. (1994) Changes in the demand for skilled labour within US manufacturing industries. Quarterly Journal of Economics, 109, 367-98.

Berman, E., Bound, J. and Machin, S. (1998) Implications of skill biased technological change: International evidence. Quarterly Journal of Economics, 113, 1245-79.

Bernard, A. and Jensen, J. (1997) Exporters, skill upgrading and the wage gap. Journal of International Economics, 42, 3-31.

Blomstrom, M. (1989) Foreign Investment and Spillovers. Routledge, London.

Blonigen, B. and Slaughter, M. (2001) Foreign-affiliate activity and US skill upgrading. Review of Economics and Statistics, 83, 362-76.

Borjas, G. and Ramey, V. (1994) Time series evidence on the sources of trends in wage inequality. American Economic Review, Papers and Proceedings, 84, 10-16.

Bound, J. and Johnson, G. (1992) Changes in the structure of wages in the 1980s: An evaluation of alternative explanations. American Economic Review, 82, 371-92.

Cantwell, J.A. (1991) The international agglomeration of R\&D. In M.C. Casson (Ed.), Global Research Strategy and International Competitiveness. Basil Blackwell, Oxford.

Caroli, E. and Van Reenen, J. (2001) Skill-biased organizational change? Evidence from a panel of British and French establishments. Quarterly Journal of Economics, 116, 144992.

Chennells, L. and Van Reenen, J. (1999) Has technology hurt less skilled workers? IFS working paper WP99/27.

Coe, D. and Helpman, E. (1995) International R\&D spillovers. European Economic Review, 39, 859-87.

Conyon, M., Girma, S., Thompson, S. and Wright, P. (2002) The impact of foreign acquisition on wages and productivity in the UK. Journal of Industrial Economics, 50, 85102.

Davies, S.W. and Lyons, B.R. (1991) Characterising relative performance: the productivity advantage of foreign owned firms in the UK. Oxford Economic Papers, 43, 584-95.

Desjonqueres, T., Machin, S. and Van Reenen, J. (1999) Another nail in the coffin? Or can the trade based explanation of changing skill structures be resurrected? Scandanavian Journal of Economics, 101, 533-54.

Driffield, N. (1996) Global Competition and the Labour Market. Harwood, Reading. 
Driffield, N. (1999) Indirect employment effects of foreign direct investment into the UK. Bulletin of Economic Research, 51, 207-21.

Driffield, N. (2001) The impact on domestic productivity of inward investment in the UK. The Manchester School, 69, 103-99.

Driffield, N. and Taylor, K. (2001) Are foreign firms more technologically intensive? UK establishment evidence from the ARD. University of Leicester PSERC WP01/9.

Dunning, J.H. (1993) Multinationals, Technology and Competitiveness. Allen \& Unwin, London.

Duranton, G. and Monastiriotis, V. (2002). Mind the gaps: The evolution of regional inequalities in the UK 1982 to 1997. Journal of Regional Science, 42, 219-56.

Feenstra, R. and Hanson, G. (1995) Foreign investment, outsourcing and relative wages. NBER Working Paper No:5121.

Feenstra, R. and Hanson, G. (1996) Globalisation, outsourcing and wage inequality. American Economic Review, 86, 240-45.

Feenstra, R. and Hanson, G. (1997) Foreign direct investment and relative wages: Evidence from Mexico's Maquiladoras. Journal of International Economics, 42, 371-93.

Figini, P. and Gorg, H. (1999) Multinational companies and wage inequality in the host country: The case of Ireland. Weltwirtschaftliches Archiv, 134, 594-612.

Girma, S., Greenaway, D. and Wakelin, K. (2001) Wages, productivity and foreign ownership in UK manufacturing. Scottish Journal of Political Economy, 48, 119-33.

Gottschalk, P. and Smeeding, T. (1997) Cross-national comparisons of earnings and income inequality. Journal of Economic Literature, 35, 633-87.

Goux, D. and Maurin, E. (2000) The decline in demand for unskilled labour: An empirical analysis method and its application to France. Review of Economics and Statistics, 82, 596-607.

Green, F., Machin, S. and Manning, A. (1996) The employer size-wage effect: Can dynamic monopsony provide an explanation? Oxford Economic Papers, 48, 433-55.

Griffith, R. and Simpson, H. (2001) Characteristics of foreign-owned firms in British Manufacturing. IFS working paper, WP01/10.

Haddad, M. and Harrison, A. (1993) Are there positive spillovers from foreign investment? Evidence from panel data for Morocco. Journal of Development Economics, 42, 51-74.

Haskel, J. (2000) The trade and labour approaches to wage inequality. Review of International Economics, 8, 397-408.

Haskel, J. and Heden, Y. (1999) Computers and the demand for skilled labour: Industry and establishment level panel evidence for the UK. Economic Journal, 109, C68-C79. 
Hubert, F. and Pain, N. (2001) Inward investment and technical progress in the United Kingdom manufacturing sector. Scottish Journal of Political Economy, 48, 134-47.

Im, K., Pesaran, M. and Shin, Y. (1997) Testing for unit roots in heterogeneous panels. Mimeo, Department of Economics, University of Cambridge.

Katz, L. and Autor, D. (1999) Changes in the wage structure and earnings inequality. In O. Ashenfelter and D. Card (Eds.), Handbook of Labor Economics: Volume 3 A. Elsevier Science, Amsterdam, The Netherlands.

Levin, A.. and Lin, C.F. (1992) Unit root tests in panel data: Asymptotic and finite sample properties. Univeristy of California at San Diego, Discussion paper No:92-93.

Levy, F. and Murnane, R. (1992) US earnings levels and earnings inequality: A review of recent trend and proposed explanations. Journal of Economic Literature, 30, 1333-81.

Machin, S. (1996) Wage inequality in the UK. Oxford Review of Economic Policy, 12, 47-64.

Machin, S. (1998) Recent shifts in wage inequality and the wage returns to education in Britain. National Institute Economic Review, 166, 87-96.

Machin, S. and Van Reenen, J. (1998) Technology and changes in skill structure: Evidence from seven OECD countries. Quarterly Journal of Economics, 113, 1215-44.

Markusen, J. (1995) The boundaries of multinational enterprises and the theory of international trade. Journal of Economic Perspectives, 9, 169-89.

Markusen, J. and Venables, A. (1998) Multinational firms and the new trade theory. Journal of International Economics, 43, 183-204.

Munday, M., Peel, M. and Taylor, K. (2003) The performance of the foreign-owned sector of UK manufacturing: Some descriptive evidence and implications for UK inward investment policy. Fiscal Studies (forthcoming).

Slaughter, M. (1999) Globalisation and wages: A tale of two perspectives. World Economy, 22, 609-29.

Stewart, M.B. (1990) Union wage differentials, product market influences and the division of rents. Economic Journal, 100, 1122-37.

Velde te, D.W. (2000) Foreign direct investment and unskilled workers in US manufacturing. Paper presented at Royal Economic Society conference at St. Andrews.

Vernon, R. (1966) International investment and international trade in the product cycle. Quarterly Journal of Economics, 80, 190-207.

Wood, A. (1994) North - South trade employment and inequality: Changing fortunes in a skill driven world. Clarendon Press, Oxford. 
Figure 1 - Domestic skilled wage share and foreign affiliate employment:

UK manufacturing 1983 to 1992

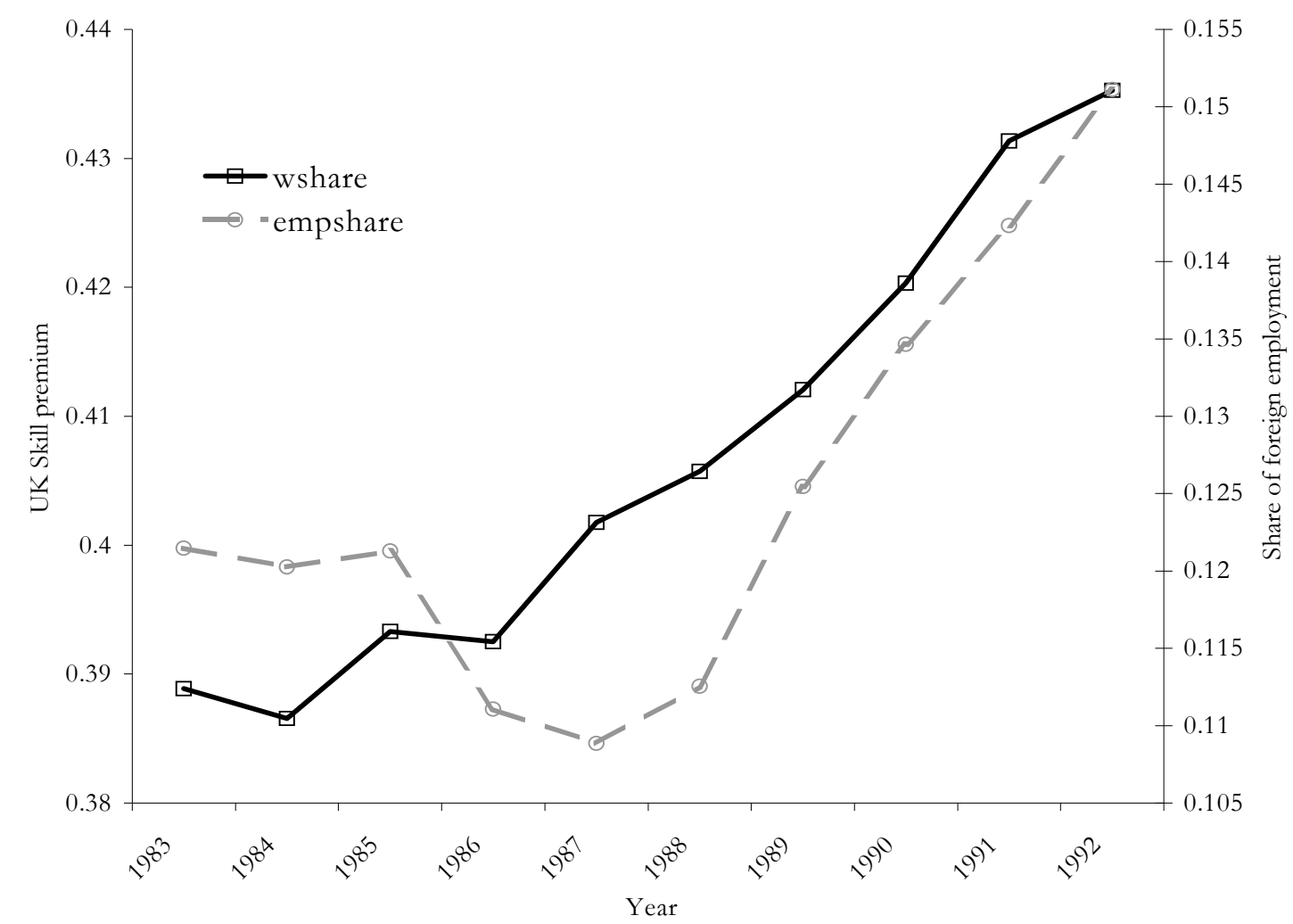

Notes: Skilled wage share in the domestic sector measured as the ratio of average (across 3 digit industries) total annual wage bill of non-operatives to average total annual wage bill of operatives in the domestic sector of UK manufacturing. Employment share is the proportion of total UK manufacturing employment accounted for by foreign owned multinationals.

Source: Census of Production, ONS. 
Table 1 - Variable definitions

\begin{tabular}{ll}
\hline Variable & Definition \\
\hline Y & Total industry value added. \\
& Research and development stock (for construction \\
& see text). \\
Imports & The value of industry imports. \\
Exports & The value of industry exports. \\
W & The wages of non-operatives. \\
W & The wages of operatives. \\
K & Capital stock (for construction see text). \\
FDI(1) & Share of total UK manufacturing employment \\
Region & accounted for by foreign owned multinationals. \\
FDI(2) & Share of Net capital expenditure by foreign firms in \\
& the 11 standard UK regions. \\
& A count of innovations used in each industry during \\
&
\end{tabular}



Table 2 - Summary statistics in levels and first differences (in parenthesis). All summary statistics are in non-log form.

\begin{tabular}{|c|c|c|c|c|c|c|c|c|}
\hline Variable & \multicolumn{2}{|c|}{ Mean } & \multicolumn{2}{|c|}{ Standard Deviation } & \multicolumn{2}{|c|}{ Minimum } & \multicolumn{2}{|c|}{ Maximum } \\
\hline$\left[\mathrm{W}_{\mathrm{s}} /\left(\mathbf{W}_{\mathrm{s}}+\mathrm{W}_{\mathrm{U}}\right)\right]$ & 0.375 & $(-0.007)$ & 0.110 & $(0.029)$ & 0.154 & $(-0.279)$ & 0.769 & $(0.187)$ \\
\hline $\mathbf{Y}$ & 171.013 & $(-0.035)$ & 53.603 & $(0.495)$ & 59.094 & $(-2.321)$ & 528.907 & $(3.396)$ \\
\hline $\mathrm{R} \& \mathrm{D} / \mathrm{Y}$ & 0.054 & $(0.002)$ & 0.177 & $(0.078)$ & 0.0004 & $(-0.907)$ & 1.741 & (0.907) \\
\hline Imports/Y & 0.460 & $(-0.005)$ & 0.625 & $(0.246)$ & 0.056 & $(-2.987)$ & 1.793 & $(2.983)$ \\
\hline Exports/Y & 0.306 & $(-0.012)$ & 0.443 & $(0.278)$ & 0.001 & $(-3.021)$ & 1.649 & $(3.064)$ \\
\hline K & 1.958 & $(-0.001)$ & 0.738 & $(0.556)$ & 0.189 & $(-3.220)$ & 3.966 & $(3.315)$ \\
\hline CR5 & 43.327 & $(-0.078)$ & 23.469 & $(0.317)$ & 6.800 & $(-3.228)$ & 100 & $(2.436)$ \\
\hline Region & 0.926 & $(-0.012)$ & 0.583 & $(0.222)$ & 0.096 & $(-1.972)$ & 3.729 & $(0.947)$ \\
\hline Innovation & 0.366 & $(-0.017)$ & 1.969 & $(1.625)$ & 0 & $(-26)$ & 31 & (17) \\
\hline FDI(1) & 0.154 & $(-0.005)$ & 0.193 & $(0.224)$ & 0 & $(-0.955)$ & 1.630 & $(0.966)$ \\
\hline FDI(2) & 0.121 & $(0.002)$ & 0.137 & $(0.269)$ & 0 & $(-0.948)$ & 0.712 & (0.947) \\
\hline Observations & & & & 1010 (909 & enced) & & & \\
\hline
\end{tabular}


Figure 2 - Correlation between skilled wage bill share and FDI employment share

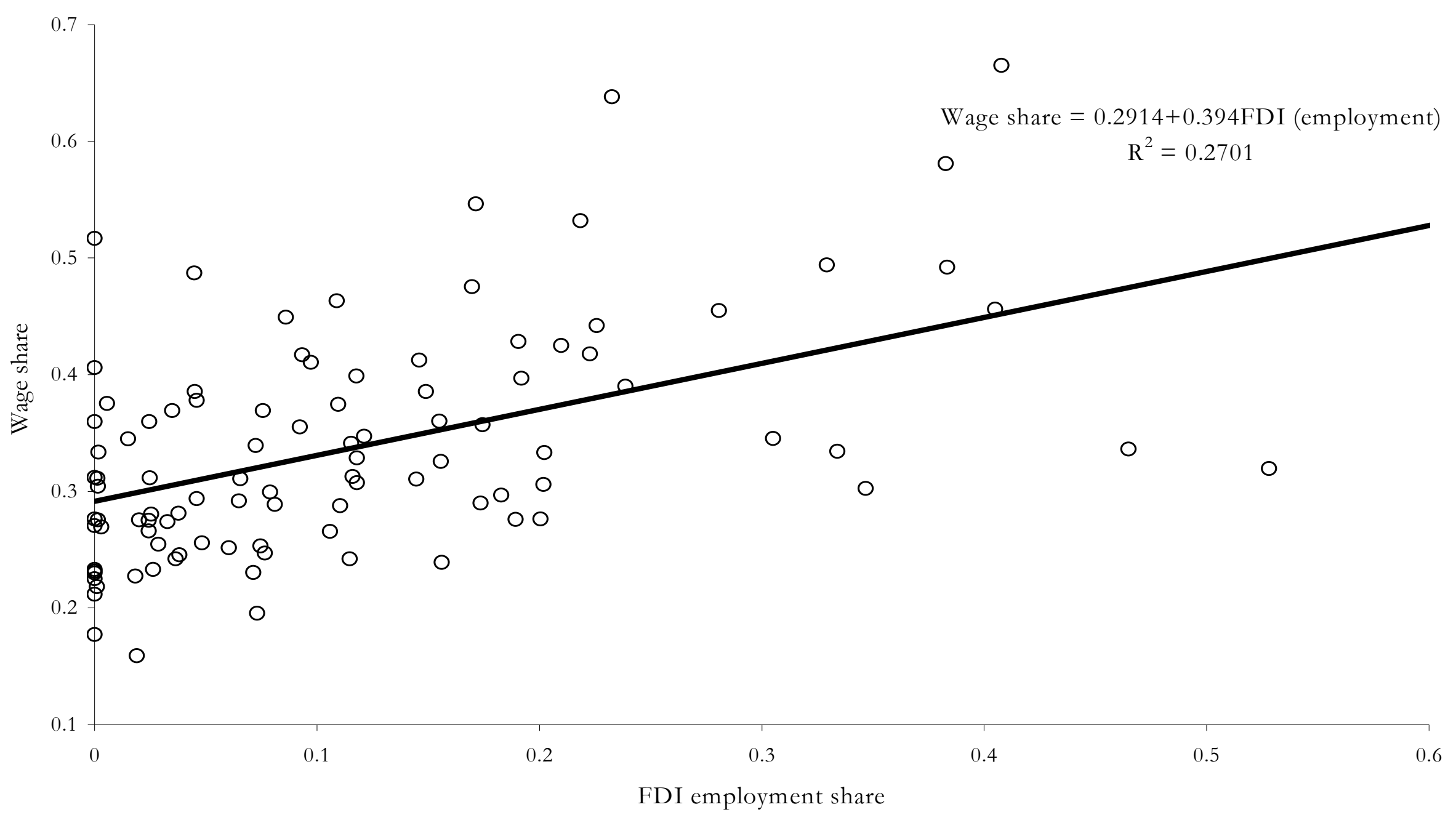


Table 3 - Domestic employment and wage decompositions

\begin{tabular}{|c|c|c|c|c|c|}
\hline & $\begin{array}{l}\text { Number of three } \\
\text { digit industries and } \\
\text { sample period }\end{array}$ & $\begin{array}{l}\text { Total change for } \\
\text { whole of } \\
\text { manufacturing }\end{array}$ & $\begin{array}{l}\text { Between industry } \\
\text { component }\end{array}$ & $\begin{array}{l}\text { Within industry } \\
\text { component }\end{array}$ & $\begin{array}{c}\text { Percentage } \\
\text { contribution of } \\
\text { within industry } \\
\text { component }\end{array}$ \\
\hline $\begin{array}{l}\text { Share of Skilled (non- } \\
\text { operatives) employment in } \\
\text { total employment }\end{array}$ & $\begin{array}{c}101 \\
(1983-1992)\end{array}$ & 0.209 & 0.028 & 0.181 & $87 \%$ \\
\hline $\begin{array}{l}\text { Share of Skilled (non- } \\
\text { operatives) wage bill in } \\
\text { total wage bill }\end{array}$ & $\begin{array}{c}101 \\
(1983-1992)\end{array}$ & 0.387 & 0.061 & 0.326 & $84 \%$ \\
\hline
\end{tabular}


Table 4 - Panel unit root tests based upon Levin and Lin.

\begin{tabular}{|c|c|c|c|c|c|c|c|c|c|c|}
\hline & \multicolumn{2}{|c|}{ Model 1} & \multicolumn{2}{|c|}{ Model 2} & \multicolumn{2}{|c|}{ Model 3} & \multicolumn{2}{|c|}{ Model 4} & \multicolumn{2}{|c|}{ Model 5} \\
\hline & $\hat{\rho}$ & $T \sqrt{N \hat{\rho}}$ & $\hat{\rho}$ & $T \sqrt{N \hat{\rho}}$ & $\hat{\rho}$ & $T \sqrt{N \hat{\rho}}$ & $\hat{\rho}$ & $T \sqrt{N \hat{\rho}}$ & $\hat{\rho}$ & $T \sqrt{N \hat{\rho}}+3 \sqrt{N}$ \\
\hline FDI(1) & 0.0949 & $27.86^{* *}$ & 0.2916 & $48.84^{* *}$ & 0.2909 & $48.78^{* *}$ & 0.2915 & $48.83^{* *}$ & 1.0468 & $251.79^{* *}$ \\
\hline FDI(2) & 0.4062 & $57.65^{* *}$ & 0.4088 & $57.83^{* *}$ & 0.4089 & $57.84^{* *}$ & 0.4086 & $64.24^{* *}$ & 0.4224 & $165.82^{* *}$ \\
\hline SW & 0.0559 & $23.76^{* *}$ & 0.0098 & $9.94^{* *}$ & 0.0257 & $16.11^{* *}$ & 0.0098 & $9.94^{* *}$ & 0.1514 & $139.60^{* *}$ \\
\hline K & 0.0192 & $13.93^{* *}$ & 0.0407 & $20.27^{* *}$ & 0.0447 & $21.24^{* *}$ & 0.0410 & $20.35^{* *}$ & 0.2830 & $153.96^{* *}$ \\
\hline Y & 0.0072 & $8.53^{* *}$ & 0.0003 & $1.74^{* *}$ & 0.0015 & $3.89^{* *}$ & 0.0002 & $1.42^{* *}$ & 0.1874 & $144.00^{* *}$ \\
\hline$(\mathrm{R} \& \mathrm{D} / \mathrm{Y})$ & 0.0031 & $5.59^{* *}$ & 0.0311 & $17.72^{* *}$ & 0.0260 & $16.20^{* *}$ & 0.0311 & $17.72^{* *}$ & 0.2969 & $155.26^{* *}$ \\
\hline (IMP/Y) & 0.0074 & $8.65^{* *}$ & 0.0021 & $4.61^{* *}$ & 0.0025 & $5.02^{* *}$ & 0.0022 & $4.71^{* *}$ & 0.0509 & $123.17^{* *}$ \\
\hline$(\mathrm{EXP} / \mathrm{Y})$ & 0.0268 & $14.81^{* *}$ & 0.0722 & $24.30^{* *}$ & 0.0740 & $24.60^{* *}$ & 0.0721 & $24.29^{* *}$ & 1.0943 & $106.17^{* *}$ \\
\hline$N$ & & & & & & 101 & & & & \\
\hline$T$ & & & & & & 10 & & & & \\
\hline
\end{tabular}

In models 1 to 4 the test statistic $T \sqrt{N \hat{\rho}}$ is normally distributed as $\mathrm{N}(0,2)$. For model 5 the test statistic $T \sqrt{N \hat{\rho}}+3 \sqrt{N}$ is normally distributed as $\mathrm{N}(0,10.2)$.

Model 1: $\Delta y_{i t}=\rho y_{i t-1}+\varepsilon_{i t}$

Model 2: $\Delta y_{i t}=\rho y_{i t-1}+\alpha_{0}+\varepsilon_{i t}$

Model 3: $\Delta y_{i t}=\rho y_{i t-1}+\alpha_{0}+\delta t+\varepsilon_{i t}$

Model 4: $\Delta y_{i t}=\rho y_{i t-1}+\theta_{t}+\varepsilon_{i t}$

Model 5: $\Delta y_{i t}=\rho y_{i t-1}+\alpha_{i}+\varepsilon_{i t}$ 
Table 5 - Panel A Fixed effects estimates of equation 6 in levels

\begin{tabular}{|c|c|c|c|c|c|c|c|c|c|c|c|c|c|c|}
\hline & \multicolumn{2}{|r|}{1} & \multicolumn{2}{|c|}{2} & \multicolumn{2}{|r|}{3} & \multicolumn{2}{|r|}{4} & \multicolumn{2}{|r|}{5} & \multicolumn{2}{|r|}{6} & \multicolumn{2}{|r|}{7} \\
\hline Intercept & -1.449 & $(21.00)$ & -1.389 & (20.44) & -1.418 & (20.73) & -1.289 & (18.74) & -1.491 & (21.77) & -1.277 & (18.53) & -1.277 & (18.54) \\
\hline $\mathrm{K}_{\mathrm{t}-1}$ & 0.035 & (3.68) & 0.033 & (3.52) & 0.035 & (3.69) & 0.030 & (3.31) & 0.036 & (3.78) & 0.030 & (3.32) & 0.029 & (3.21) \\
\hline$(\mathrm{R} \& \mathrm{D} / \mathrm{Y})_{\mathrm{t}-1}$ & 0.024 & (4.01) & & - & & - & 0.034 & (5.93) & & - & 0.034 & (5.91) & 0.034 & (5.85) \\
\hline$(\operatorname{Imp} / \mathrm{Y})$ & & - & 0.057 & (7.33) & & - & 0.074 & (4.81) & & - & 0.072 & $(4.70)$ & 0.072 & $(4.72)$ \\
\hline FDI & & - & & - & & - & & - & 0.008 & (2.15) & 0.007 & (2.91) & 0.006 & (2.00) \\
\hline $\mathrm{FDI}^{2}$ & & - & & - & & - & & - & & - & & - & & - \\
\hline $\mathrm{FDI}_{\mathrm{t}-1}$ & & - & & - & & - & & - & & - & & - & & - \\
\hline \multicolumn{15}{|l|}{ Controls } \\
\hline CR5 & 0.365 & $(6.53)$ & 0.348 & (6.11) & 0.355 & (6.31) & 0.326 & (5.14) & 0.369 & $(6.65)$ & 0.319 & (4.72) & 0.322 & (4.90) \\
\hline Adjusted $\mathrm{R}^{2}$ & \multicolumn{2}{|c|}{0.845} & \multicolumn{2}{|c|}{0.869} & \multicolumn{2}{|c|}{0.860} & \multicolumn{2}{|c|}{0.877} & \multicolumn{2}{|c|}{0.842} & \multicolumn{2}{|c|}{0.879} & \multicolumn{2}{|c|}{0.879} \\
\hline
\end{tabular}

Absolute White robust $\mathrm{T}$ - ratios are shown in parenthesis. ${ }^{*}$ Significant at the $1 \%$ level. Observations are less than 1010 due to time lags, each lag reduces the sample by 101. Estimation is based upon data weighted by the industry wage bill. 
Table 5 - Panel B Fixed effects estimates of equations 6 and 6' in levels

\begin{tabular}{|c|c|c|c|c|c|c|c|c|c|c|c|c|}
\hline & \multicolumn{2}{|r|}{8} & \multicolumn{2}{|c|}{9} & \multicolumn{2}{|c|}{10} & \multicolumn{2}{|c|}{11} & \multicolumn{2}{|c|}{12} & \multicolumn{2}{|c|}{13} \\
\hline Intercept & -1.277 & (18.34) & -1.278 & $(18.46)$ & -1.267 & (18.32) & -1.275 & $(18.45)$ & -1.279 & (18.47) & -1.288 & (18.56) \\
\hline $\mathrm{K}_{\mathrm{t}-1}$ & 0.030 & (3.31) & 0.029 & (3.20) & 0.031 & (3.34) & 0.030 & (3.22) & 0.031 & (3.34) & 0.030 & (3.23) \\
\hline$Y_{t-1}$ & 0.123 & (4.18) & 0.121 & (4.14) & 0.125 & $(4.27)$ & 0.122 & (4.15) & 0.133 & (4.50) & 0.128 & (4.35) \\
\hline$(\mathrm{R} \& \mathrm{D} / \mathrm{Y})_{\mathrm{t}-1}$ & 0.034 & (5.88) & 0.034 & (5.84) & 0.034 & (5.97) & 0.034 & (5.86) & 0.035 & (6.12) & 0.035 & (5.99) \\
\hline$(\operatorname{Imp} / \mathrm{Y})$ & 0.072 & (4.66) & 0.072 & (4.71) & 0.069 & (4.54) & 0.072 & (4.71) & 0.070 & (4.58) & 0.073 & $(4.77)$ \\
\hline$(\operatorname{Exp} / Y)$ & -0.006 & $(0.38)$ & -0.006 & $(0.37)$ & -0.002 & (0.10) & -0.005 & $(0.35)$ & -0.002 & (0.10) & -0.006 & (0.38) \\
\hline FDI & 0.007 & (2.91) & 0.006 & $(2.00)$ & 0.023 & (2.20) & 0.009 & (2.10) & 0.026 & $(2.47)$ & 0.010 & (2.25) \\
\hline $\mathrm{FDI}^{2}$ & \multicolumn{2}{|r|}{-} & \multicolumn{2}{|r|}{-} & -0.007 & (1.75) & -0.001 & $(0.40)$ & -0.008 & (1.92) & 0.001 & $(0.55)$ \\
\hline $\mathrm{FDI}_{\mathrm{t}-1}$ & 0.001 & $(0.05)$ & -0.001 & $(0.06)$ & \multicolumn{2}{|r|}{-} & \multicolumn{2}{|c|}{-} & \multicolumn{2}{|c|}{-} & \multicolumn{2}{|c|}{-} \\
\hline Innovation & \multicolumn{2}{|r|}{-} & \multicolumn{2}{|r|}{-} & \multicolumn{2}{|r|}{-} & \multicolumn{2}{|c|}{-} & 0.0006 & (2.02) & 0.0006 & (1.81) \\
\hline \multicolumn{13}{|l|}{ Controls } \\
\hline CR5 & 0.319 & $(4.70)$ & 0.322 & (4.89) & 0.315 & (4.39) & 0.321 & $(4.76)$ & 0.315 & (4.41) & 0.321 & $(4.80)$ \\
\hline Region & 0.030 & (3.47) & 0.031 & (3.51) & 0.029 & (3.41) & 0.031 & (3.51) & 0.031 & (3.57) & 0.032 & (3.65) \\
\hline Time & \multicolumn{12}{|c|}{$y e s^{* *}$} \\
\hline Observations & \multicolumn{12}{|c|}{909} \\
\hline Adjusted $\mathrm{R}^{2}$ & \multicolumn{2}{|c|}{0.879} & \multicolumn{2}{|c|}{0.879} & \multicolumn{2}{|c|}{0.878} & \multicolumn{2}{|c|}{0.879} & \multicolumn{2}{|c|}{0.877} & \multicolumn{2}{|c|}{0.878} \\
\hline
\end{tabular}

Absolute White robust $\mathrm{T}$ - ratios are shown in parenthesis. ${ }^{*}$ Significant at the $1 \%$ level. Observations are less than 1010 due to time lags, each lag reduces the sample by 101 . Estimation is based upon data weighted by the industry wage bill. 
Table 6 - Panel A GMM estimates of equation 6" in first differences

\begin{tabular}{|c|c|c|c|c|c|c|c|c|c|c|c|c|c|c|}
\hline & \multicolumn{2}{|r|}{1} & \multicolumn{2}{|c|}{2} & \multicolumn{2}{|r|}{3} & \multicolumn{2}{|c|}{4} & \multicolumn{2}{|r|}{5} & \multicolumn{2}{|c|}{6} & \multicolumn{2}{|c|}{7} \\
\hline Lagged SW & 0.466 & (3.77) & 0.455 & (3.64) & 0.466 & (3.77) & 0.479 & (3.91) & 0.435 & (3.61) & 0.482 & (4.01) & 0.479 & (3.93) \\
\hline$\Delta \mathrm{K}$ & 0.013 & $(1.82)$ & 0.015 & (1.98) & 0.014 & (1.89) & 0.010 & (1.65) & 0.018 & (2.03) & 0.010 & (1.67) & 0.010 & (1.65) \\
\hline$\Delta \mathrm{Y}$ & 0.044 & (2.15) & 0.039 & (2.07) & 0.043 & (2.15) & 0.049 & (2.27) & 0.028 & (1.74) & 0.051 & (2.33) & 0.049 & (2.28) \\
\hline$\Delta(\mathrm{R} \& \mathrm{D} / \mathrm{Y})$ & 0.017 & (1.87) & & - & & - & 0.024 & (2.49) & & - & 0.024 & (2.48) & 0.024 & (2.49) \\
\hline$\Delta(\operatorname{Imp} / \mathrm{Y})$ & & - & 0.027 & (2.41) & & - & 0.039 & (1.81) & & - & 0.036 & (1.79) & 0.039 & $(1.80)$ \\
\hline$\Delta(\operatorname{Exp} / \mathrm{Y})$ & & & & & 0.022 & (1.41) & 0.004 & $(0.20)$ & & - & 0.003 & $(0.15)$ & 0.004 & $(0.22)$ \\
\hline$\Delta \mathrm{FDI}$ & & - & & - & & - & & - & 0.007 & $(2.70)$ & 0.005 & (2.14) & 0.003 & (1.91) \\
\hline$\Delta \mathrm{FDI}^{2}$ & & - & & - & & - & & - & & - & & - & & - \\
\hline$\Delta \mathrm{FDI}_{\mathrm{t}-1}$ & & - & & - & & - & & - & & - & & - & & - \\
\hline Controls & & & & & & & & & & & & & & \\
\hline$\Delta \mathrm{CR} 5$ & 0.336 & $(5.47)$ & 0.334 & (5.53) & 0.332 & (5.44) & 0.322 & (5.37) & 0.356 & (6.02) & 0.317 & $(5.42)$ & 0.320 & (5.43) \\
\hline$\Delta$ Region & 0.037 & $(3.45)$ & 0.037 & (3.52) & 0.035 & (3.34) & 0.034 & (3.26) & 0.036 & (3.83) & 0.034 & (3.26) & 0.034 & (3.29) \\
\hline Sargan test & 55.51 & {$[0.015]$} & 52.29 & {$[0.030]$} & 54.80 & [0.019] & 55.03 & {$[0.017]$} & 54.32 & {$[0.019]$} & 53.74 & {$[0.022]$} & 54.24 & {$[0.020]$} \\
\hline $2^{\text {nd }}$ order AR & 0.11 & {$[0.914]$} & 0.34 & {$[0.735]$} & 0.27 & {$[0.786]$} & 0.11 & {$[0.916]$} & 0.16 & {$[0.875]$} & 0.03 & {$[0.978]$} & 0.03 & {$[0.978]$} \\
\hline $\begin{array}{l}\text { Time } \\
\text { Observations }\end{array}$ & & & & & & & & $\begin{array}{l}y e s^{* *} \\
707\end{array}$ & & & & & & \\
\hline
\end{tabular}

Absolute White robust T- ratios are shown in parenthesis. ${ }^{*}$ Significant at the $1 \%$ level. Observations are less than 1010 due to time lags, each lag reduces the sample by 101, and instrumentation. A full set of instruments are used in the estimation by GMM - see text. Estimation is based upon data weighted by the industry wage bill. $\Delta$ denotes first differences. 
Table 6 - Panel B GMM estimates of equations 6" and 6" in first differences

\begin{tabular}{|c|c|c|c|c|c|c|c|c|c|c|c|c|}
\hline & \multicolumn{2}{|r|}{8} & \multicolumn{2}{|c|}{9} & \multicolumn{2}{|r|}{10} & \multicolumn{2}{|r|}{11} & \multicolumn{2}{|r|}{12} & \multicolumn{2}{|r|}{13} \\
\hline Lagged SW & 0.494 & (4.11) & 0.481 & (3.97) & 0.457 & (3.87) & 0.464 & (3.90) & 0.454 & (3.21) & 0.471 & $(3.25)$ \\
\hline$\Delta \mathrm{K}$ & 0.010 & $(1.65)$ & 0.010 & (1.65) & 0.010 & (1.61) & 0.010 & (1.63) & 0.010 & (1.69) & 0.010 & $(1.62)$ \\
\hline$\Delta \mathrm{Y}$ & 0.045 & (2.13) & 0.049 & (2.26) & 0.047 & (2.54) & 0.048 & $(2.25)$ & 0.060 & (1.77) & 0.051 & $(2.50)$ \\
\hline$\Delta(\mathrm{R} \& \mathrm{D} / \mathrm{Y})$ & 0.024 & $(2.46)$ & 0.024 & (2.49) & 0.025 & (2.51) & 0.024 & $(2.51)$ & 0.025 & (2.53) & 0.024 & (2.83) \\
\hline$\Delta(\operatorname{Imp} / \mathrm{Y})$ & 0.036 & $(2.65)$ & 0.039 & (2.79) & 0.040 & (2.47) & 0.044 & (2.10) & 0.049 & $(2.75)$ & 0.043 & (2.12) \\
\hline$\Delta(\operatorname{Exp} / Y)$ & 0.004 & (0.18) & 0.005 & $(0.23)$ & 0.014 & $(0.71)$ & 0.010 & $(0.46)$ & 0.013 & (2.69) & 0.010 & $(0.52)$ \\
\hline$\Delta \mathrm{FDI}$ & 0.007 & $(2.25)$ & 0.003 & (1.84) & 0.028 & (2.29) & 0.024 & (2.11) & 0.028 & $(2.68)$ & 0.023 & $(2.21)$ \\
\hline$\Delta \mathrm{FDI}^{2}$ & & - & & - & -0.016 & (2.34) & -0.009 & (2.19) & -0.016 & $(2.26)$ & -0.009 & (2.18) \\
\hline$\Delta \mathrm{FDI}_{\mathrm{t}-1}$ & 0.004 & (1.01) & 0.001 & $(0.10)$ & & - & & - & & - & & - \\
\hline Innovation & & - & & - & & - & & - & -0.0001 & $(0.29)$ & -0.0003 & $(0.53)$ \\
\hline \multicolumn{13}{|l|}{ Controls } \\
\hline$\Delta \mathrm{CR} 5$ & 0.336 & $(5.46)$ & 0.339 & (5.46) & 0.299 & (5.48) & 0.310 & (5.49) & 0.298 & (5.92) & 0.308 & $(5.31)$ \\
\hline$\Delta$ Region & 0.034 & (3.24) & 0.034 & (3.26) & 0.035 & (3.68) & 0.034 & $(3.46)$ & 0.035 & (3.50) & 0.034 & (3.37) \\
\hline Sargan test & 52.30 & {$[0.030]$} & 54.10 & {$[0.021]$} & 53.96 & {$[0.021]$} & 53.41 & {$[0.024]$} & 52.83 & {$[0.021]$} & 52.30 & {$[0.024]$} \\
\hline $2^{\text {nd }}$ order AR & 0.09 & {$[0.931]$} & 0.08 & {$[0.936]$} & 0.11 & {$[0.909]$} & 0.02 & {$[0.985]$} & 0.15 & {$[0.881]$} & 0.03 & {$[0.977]$} \\
\hline Time & \multicolumn{12}{|c|}{$y e s^{* *}$} \\
\hline Observations & & & & & & & 707 & & & & & \\
\hline
\end{tabular}

Absolute White robust T- ratios are shown in parenthesis. ${ }^{*}$ Significant at the $1 \%$ level. Observations are less than 1010 due to time lags, each lag reduces the sample by 101, and instrumentation. A full set of instruments are used in the estimation by GMM - see text. Estimation is based upon data weighted by the industry wage bill. $\Delta$ denotes first differences. 
Table 7 - The impact of potential demand shifters upon wage inequality 1983 to 1992

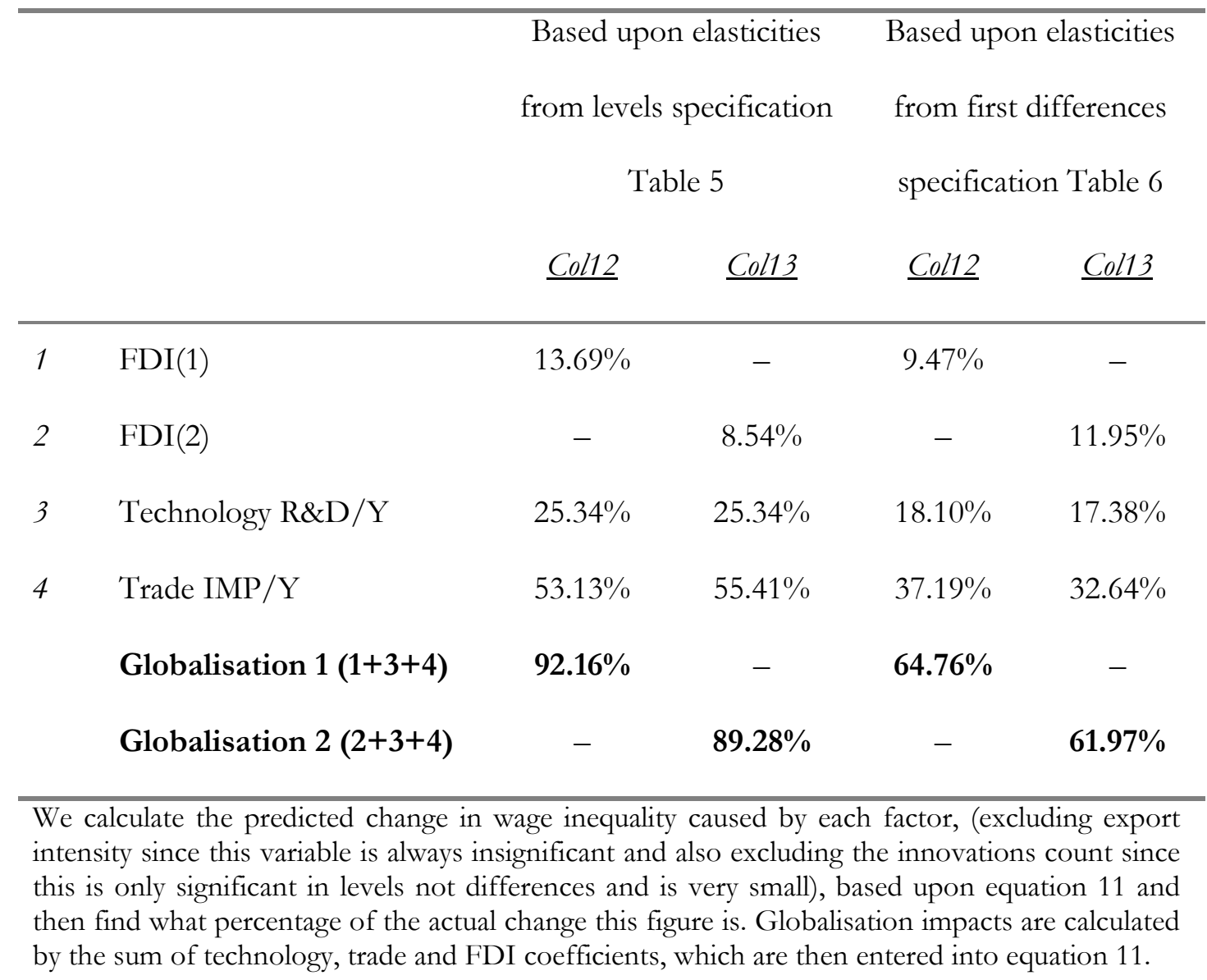



APPENDIX Table A1 - Industry descriptions (sic80) and summary statistics, 1983 to 1992

\begin{tabular}{|c|c|c|c|c|c|c|c|c|c|}
\hline \multirow[b]{2}{*}{ sic 1980} & \multirow[b]{2}{*}{ Industry description } & \multicolumn{4}{|c|}{ FDI employment } & \multicolumn{4}{|c|}{ FDI capital } \\
\hline & & Mean & Standard deviation & $\operatorname{Max}$ & Min & Mean & Standard deviation & $\operatorname{Max}$ & Min \\
\hline 221 & Iron and steel industry & 0.0253 & 0.0136 & 0.0371 & 0.0000 & 0.0246 & 0.0163 & 0.0495 & 0.0000 \\
\hline 222 & Steel tubes & 0.0377 & 0.0277 & 0.0679 & 0.0000 & 0.0226 & 0.0312 & 0.0928 & 0.0000 \\
\hline 223 & $\begin{array}{l}\text { Drawing, cold rolling and cold } \\
\text { forming of steel }\end{array}$ & 0.1058 & 0.0589 & 0.2030 & 0.0399 & 0.1739 & 0.1141 & 0.4404 & 0.0560 \\
\hline 224 & Non-ferrous metal industry & 0.3466 & 0.0555 & 0.3997 & 0.1934 & 0.4537 & 0.0821 & 0.6064 & 0.3280 \\
\hline 239 & $\begin{array}{l}\text { Extraction of other minerals not } \\
\text { elsewhere specified }\end{array}$ & 0.0011 & 0.0036 & 0.0114 & 0.0000 & 0.0009 & 0.0027 & 0.0085 & 0.0000 \\
\hline 241 & Structural clay products & 0.0000 & 0.0000 & 0.0000 & 0.0000 & 0.0000 & 0.0000 & 0.0000 & 0.0000 \\
\hline 242 & Cement, lime and plaster & 0.0000 & 0.0000 & 0.0000 & 0.0000 & 0.0000 & 0.0000 & 0.0000 & 0.0000 \\
\hline 243 & $\begin{array}{l}\text { Building products of concrete, } \\
\text { cement or plaster }\end{array}$ & 0.0789 & 0.0138 & 0.0977 & 0.0580 & 0.0565 & 0.0214 & 0.0794 & 0.0141 \\
\hline 244 & Asbestos goods & 0.0000 & 0.0000 & 0.0000 & 0.0000 & 0.0000 & 0.0000 & 0.0000 & 0.0000 \\
\hline 245 & $\begin{array}{l}\text { Working of stone and other non- } \\
\text { metallic minerals not elsewhere } \\
\text { specified }\end{array}$ & 0.0649 & 0.0113 & 0.0796 & 0.0450 & 0.0740 & 0.0211 & 0.1047 & 0.0427 \\
\hline 246 & Abrasive products & 0.1177 & 0.0640 & 0.2280 & 0.0000 & 0.1970 & 0.1989 & 0.5292 & 0.0000 \\
\hline 247 & Glass and glassware & 0.1105 & 0.0440 & 0.1895 & 0.0610 & 0.1688 & 0.1171 & 0.4178 & 0.0291 \\
\hline 248 & Refractory and ceramic goods & 0.1146 & 0.0458 & 0.1747 & 0.0552 & 0.1465 & 0.1405 & 0.5327 & 0.0506 \\
\hline 251 & Basic industrial chemicals & 0.2257 & 0.0195 & 0.2500 & 0.1973 & 0.2905 & 0.0947 & 0.5358 & 0.2059 \\
\hline 255 & Paints, varnishes and printing ink & 0.2184 & 0.0297 & 0.2493 & 0.1596 & 0.2507 & 0.1117 & 0.4501 & 0.1108 \\
\hline 256 & $\begin{array}{l}\text { Specialised chemical products } \\
\text { mainly for industrial/agricultural } \\
\text { process }\end{array}$ & 0.3292 & 0.0592 & 0.4143 & 0.2551 & 0.3686 & 0.0594 & 0.4356 & 0.2361 \\
\hline 257 & Pharmaceutical products & 0.3827 & 0.0266 & 0.4212 & 0.3275 & 0.3527 & 0.0752 & 0.4794 & 0.2484 \\
\hline 258 & Soap and toilet preparations & 0.3832 & 0.0383 & 0.4393 & 0.2988 & 0.4297 & 0.1132 & 0.5396 & 0.1643 \\
\hline 259 & $\begin{array}{l}\text { Specialised chemical products } \\
\text { mainly for household and office use }\end{array}$ & 0.6470 & 0.0463 & 0.7123 & 0.5801 & 0.7595 & 0.1037 & 1.0165 & 0.6453 \\
\hline 260 & Production of man-made fibres & 0.1180 & 0.0321 & 0.1909 & 0.0832 & 0.1257 & 0.1758 & 0.4686 & 0.0000 \\
\hline 311 & Foundries & 0.0713 & 0.0387 & 0.1362 & 0.0336 & 0.1091 & 0.0822 & 0.2834 & 0.0291 \\
\hline 312 & Forging, pressing and stamping & 0.0364 & 0.0230 & 0.0949 & 0.0145 & 0.0502 & 0.0709 & 0.2390 & 0.0000 \\
\hline
\end{tabular}




\begin{tabular}{|c|c|c|c|c|c|c|c|c|c|}
\hline \multirow[b]{2}{*}{ sic 1980} & \multirow[b]{2}{*}{ Industry description } & \multicolumn{4}{|c|}{ FDI employment } & \multicolumn{4}{|c|}{ FDI capital } \\
\hline & & Mean & Standard deviation & $\operatorname{Max}$ & Min & Mean & Standard deviation & $\operatorname{Max}$ & Min \\
\hline 313 & $\begin{array}{l}\text { Bolt, nuts, etc.; springs; non- } \\
\text { precision chains; metal treatment }\end{array}$ & 0.0811 & 0.0124 & 0.1023 & 0.0677 & 0.1148 & 0.0388 & 0.1647 & 0.0548 \\
\hline 314 & Metal doors; windows etc. & 0.0459 & 0.0144 & 0.0722 & 0.0282 & 0.0503 & 0.0491 & 0.1354 & 0.0000 \\
\hline 316 & $\begin{array}{l}\text { Hand tools and finished metal } \\
\text { goods }\end{array}$ & 0.1160 & 0.0124 & 0.1322 & 0.0973 & 0.2063 & 0.0557 & 0.3215 & 0.1342 \\
\hline 320 & Industrial plant and steelwork & 0.0725 & 0.0165 & 0.1100 & 0.0498 & 0.1115 & 0.0962 & 0.3132 & 0.0141 \\
\hline 321 & Agricultural machinery and tractors & 0.4648 & 0.0529 & 0.5126 & 0.3537 & 0.5669 & 0.3194 & 0.8773 & 0.0000 \\
\hline 322 & $\begin{array}{l}\text { Metal-working machine tools and } \\
\text { engineers' tools }\end{array}$ & 0.1179 & 0.0170 & 0.1431 & 0.0943 & 0.1434 & 0.0634 & 0.2571 & 0.0000 \\
\hline 323 & Textile machinery & 0.1212 & 0.0846 & 0.2032 & 0.0000 & 0.0550 & 0.0938 & 0.2553 & 0.0000 \\
\hline 324 & $\begin{array}{l}\text { Machine for food; chemical and } \\
\text { related industries; process } \\
\text { engineering contractors }\end{array}$ & 0.2327 & 0.0163 & 0.2573 & 0.2121 & 0.3942 & 0.4395 & 1.6304 & 0.1597 \\
\hline 325 & $\begin{array}{l}\text { Mining machinery; construction and } \\
\text { mechanical handling equipment }\end{array}$ & 0.2386 & 0.0270 & 0.2941 & 0.2066 & 0.2989 & 0.0901 & 0.4604 & 0.2016 \\
\hline 326 & $\begin{array}{l}\text { Mechanical power transmission } \\
\text { equipment }\end{array}$ & 0.1557 & 0.0699 & 0.2646 & 0.0923 & 0.3113 & 0.1285 & 0.5091 & 0.1456 \\
\hline 327 & $\begin{array}{l}\text { Machinery for printing, paper, } \\
\text { wood, leather, rubber, glass and } \\
\text { related industries; laundry and dry } \\
\text { cleaning machinery }\end{array}$ & 0.2098 & 0.0473 & 0.3267 & 0.1646 & 0.2264 & 0.0814 & 0.3955 & 0.1097 \\
\hline 328 & $\begin{array}{l}\text { Other machinery and mechanical } \\
\text { equipment }\end{array}$ & 0.1918 & 0.0046 & 0.1986 & 0.1852 & 0.2438 & 0.0299 & 0.2793 & 0.1885 \\
\hline 329 & $\begin{array}{l}\text { Ordnance, small arms and } \\
\text { ammunition }\end{array}$ & 0.0350 & 0.0306 & 0.0689 & 0.0000 & 0.0088 & 0.0279 & 0.0882 & 0.0000 \\
\hline 330 & $\begin{array}{l}\text { Manufacture of office machinery } \\
\text { and data processing equipment }\end{array}$ & 0.4078 & 0.1110 & 0.5820 & 0.2908 & 0.5860 & 0.0909 & 0.7556 & 0.4243 \\
\hline 341 & Insulated wires and cables & 0.1154 & 0.0612 & 0.2247 & 0.0310 & 0.1458 & 0.0949 & 0.3083 & 0.0229 \\
\hline 342 & Basic electrical equipment & 0.0972 & 0.0601 & 0.2663 & 0.0605 & 0.1103 & 0.0696 & 0.2992 & 0.0532 \\
\hline 343 & $\begin{array}{l}\text { Electrical equipment for industrial } \\
\text { use; batteries and accumulators }\end{array}$ & 0.1460 & 0.0113 & 0.1610 & 0.1224 & 0.1779 & 0.0603 & 0.2746 & 0.1023 \\
\hline
\end{tabular}




\begin{tabular}{|c|c|c|c|c|c|c|c|c|c|}
\hline \multirow[b]{2}{*}{ sic 1980} & \multirow[b]{2}{*}{ Industry description } & \multicolumn{4}{|c|}{ FDI employment } & \multicolumn{4}{|c|}{ FDI capital } \\
\hline & & Mean & Standard deviation & $\operatorname{Max}$ & Min & Mean & Standard deviation & $\operatorname{Max}$ & Min \\
\hline 344 & $\begin{array}{l}\text { Telecommunications equipment; } \\
\text { electrical measuring equipment; } \\
\text { electronic capital goods and passive } \\
\text { electronic components }\end{array}$ & 0.1713 & 0.0395 & 0.2327 & 0.1261 & 0.2492 & 0.0891 & 0.4356 & 0.1460 \\
\hline 345 & Other electronic equipment & 0.4048 & 0.0578 & 0.5102 & 0.3510 & 0.5533 & 0.1035 & 0.7149 & 0.3836 \\
\hline 346 & Domestic-type electric appliances & 0.3051 & 0.0405 & 0.3622 & 0.2572 & 0.3225 & 0.0934 & 0.4933 & 0.1960 \\
\hline 347 & $\begin{array}{l}\text { Electric lamps and other electric } \\
\text { lighting equipment }\end{array}$ & 0.0933 & 0.0468 & 0.1884 & 0.0618 & 0.1394 & 0.1059 & 0.3431 & 0.0472 \\
\hline 351 & Motor vehicles and their engines & 0.5279 & 0.0649 & 0.6225 & 0.4519 & 0.6314 & 0.1377 & 0.8248 & 0.5015 \\
\hline 352 & $\begin{array}{l}\text { Motor vehicles bodies, trailers and } \\
\text { caravans }\end{array}$ & 0.0746 & 0.0116 & 0.0900 & 0.0554 & 0.0854 & 0.0516 & 0.1866 & 0.0308 \\
\hline 353 & Motor vehicle parts & 0.1894 & 0.0386 & 0.2650 & 0.1520 & 0.2558 & 0.0962 & 0.4635 & 0.1375 \\
\hline 361 & Shipbuilding and repairing & 0.0248 & 0.0247 & 0.0753 & 0.0000 & 0.0371 & 0.0508 & 0.1384 & 0.0000 \\
\hline 362 & Railway and tramway vehicles & 0.0327 & 0.0472 & 0.1495 & 0.0000 & 0.0588 & 0.1156 & 0.3716 & 0.0000 \\
\hline 363 & Cycles and motor cycles & 0.0000 & 0.0000 & 0.0000 & 0.0000 & 0.0000 & 0.0000 & 0.0000 & 0.0000 \\
\hline 364 & $\begin{array}{l}\text { Aerospace equipment manufacture } \\
\text { and repair }\end{array}$ & 0.0448 & 0.0364 & 0.1073 & 0.0163 & 0.1012 & 0.0785 & 0.2246 & 0.0299 \\
\hline 365 & Other vehicles & 0.0000 & 0.0000 & 0.0000 & 0.0000 & 0.0000 & 0.0000 & 0.0000 & 0.0000 \\
\hline 371 & $\begin{array}{l}\text { Measuring, checking and precision } \\
\text { instruments and apparatus }\end{array}$ & 0.1697 & 0.0270 & 0.2082 & 0.1154 & 0.2090 & 0.0538 & 0.3174 & 0.1595 \\
\hline 372 & $\begin{array}{l}\text { Medical and surgical equipment and } \\
\text { orthopaedic appliances }\end{array}$ & 0.1907 & 0.0604 & 0.3167 & 0.1282 & 0.3976 & 0.1617 & 0.6423 & 0.1783 \\
\hline 373 & $\begin{array}{l}\text { Optical precision instruments and } \\
\text { photographic equipment }\end{array}$ & 0.2808 & 0.1040 & 0.3676 & 0.0000 & 0.3005 & 0.1297 & 0.5248 & 0.0000 \\
\hline 374 & $\begin{array}{l}\text { Clocks, watches and other timing } \\
\text { devices }\end{array}$ & 0.2228 & 0.1372 & 0.3381 & 0.0000 & 0.2136 & 0.2039 & 0.5971 & 0.0000 \\
\hline 411 & $\begin{array}{l}\text { Organic oils and fats (other than } \\
\text { crude animal fats) }\end{array}$ & 0.0451 & 0.0583 & 0.1235 & 0.0000 & 0.0781 & 0.1133 & 0.3207 & 0.0000 \\
\hline 412 & $\begin{array}{l}\text { Slaughtering of animals and } \\
\text { production of meat and by products }\end{array}$ & 0.0730 & 0.0266 & 0.1093 & 0.0428 & 0.0679 & 0.0336 & 0.1259 & 0.0379 \\
\hline 413 & $\begin{array}{l}\text { Preparation of milk and milk } \\
\text { products }\end{array}$ & 0.0764 & 0.0229 & 0.1205 & 0.0494 & 0.0929 & 0.0390 & 0.1547 & 0.0384 \\
\hline
\end{tabular}




\begin{tabular}{|c|c|c|c|c|c|c|c|c|c|}
\hline \multirow[b]{2}{*}{ sic 1980} & \multirow[b]{2}{*}{ Industry description } & \multicolumn{4}{|c|}{ FDI employment } & \multicolumn{4}{|c|}{ FDI capital } \\
\hline & & Mean & Standard deviation & $\operatorname{Max}$ & Min & Mean & Standard deviation & $\operatorname{Max}$ & Min \\
\hline 414 & Preparation of fruit and vegetables & 0.1560 & 0.0313 & 0.1938 & 0.1119 & 0.1750 & 0.0452 & 0.2401 & 0.0998 \\
\hline 415 & Fish processing & 0.0484 & 0.0417 & 0.1425 & 0.0000 & 0.0449 & 0.0386 & 0.1187 & 0.0000 \\
\hline 416 & Grain milling & 0.0018 & 0.0056 & 0.0176 & 0.0000 & 0.0009 & 0.0027 & 0.0085 & 0.0000 \\
\hline 419 & $\begin{array}{l}\text { Bread, biscuits and flour } \\
\text { confectionery }\end{array}$ & 0.0191 & 0.0201 & 0.0552 & 0.0000 & 0.0291 & 0.0341 & 0.0862 & 0.0000 \\
\hline 420 & Sugar and sugar by-products & 0.0000 & 0.0000 & 0.0000 & 0.0000 & 0.0000 & 0.0000 & 0.0000 & 0.0000 \\
\hline 421 & $\begin{array}{l}\text { Ice cream, cocoa, chocolate and } \\
\text { sugar confectionery }\end{array}$ & 0.1735 & 0.1079 & 0.3212 & 0.0637 & 0.2022 & 0.1561 & 0.4064 & 0.0297 \\
\hline 422 & Animal feed stuffs & 0.0860 & 0.0727 & 0.1932 & 0.0000 & 0.1171 & 0.1239 & 0.2988 & 0.0000 \\
\hline 423 & Miscellaneous foods & 0.3341 & 0.0141 & 0.3549 & 0.3153 & 0.5017 & 0.0689 & 0.6415 & 0.4298 \\
\hline 424 & Spirit distilling and compounding & 0.1550 & 0.0345 & 0.2103 & 0.1220 & 0.2133 & 0.1069 & 0.4899 & 0.0976 \\
\hline 426 & Wines, cider and perry & 0.0000 & 0.0000 & 0.0000 & 0.0000 & 0.0000 & 0.0000 & 0.0000 & 0.0000 \\
\hline 427 & Brewing and malting & 0.0246 & 0.0411 & 0.0991 & 0.0000 & 0.0121 & 0.0273 & 0.0810 & 0.0000 \\
\hline 428 & Soft drinks & 0.0922 & 0.0824 & 0.2829 & 0.0000 & 0.1292 & 0.1246 & 0.4220 & 0.0000 \\
\hline 429 & Tobacco industry & 0.1491 & 0.2414 & 0.5438 & 0.0000 & 0.1722 & 0.2828 & 0.7085 & 0.0000 \\
\hline 431 & Woollen and worsted industry & 0.0184 & 0.0109 & 0.0349 & 0.0000 & 0.0177 & 0.0145 & 0.0406 & 0.0000 \\
\hline 432 & Cotton and silk industries & 0.0604 & 0.0222 & 0.0956 & 0.0337 & 0.1142 & 0.1297 & 0.4504 & 0.0000 \\
\hline 433 & $\begin{array}{l}\text { Throwing, texturing, etc. of } \\
\text { continuous filament yam }\end{array}$ & 0.0000 & 0.0000 & 0.0000 & 0.0000 & 0.0000 & 0.0000 & 0.0000 & 0.0000 \\
\hline 434 & $\begin{array}{l}\text { Spinning and weaving of flax; hemp } \\
\text { and ramie }\end{array}$ & 0.0000 & 0.0000 & 0.0000 & 0.0000 & 0.0000 & 0.0000 & 0.0000 & 0.0000 \\
\hline 435 & $\begin{array}{l}\text { Jute and polypropylene yarns and } \\
\text { fabrics }\end{array}$ & 0.0000 & 0.0000 & 0.0000 & 0.0000 & 0.0000 & 0.0000 & 0.0000 & 0.0000 \\
\hline 436 & Hosiery and other knitted goods & 0.0287 & 0.0260 & 0.0834 & 0.0000 & 0.0165 & 0.0176 & 0.0613 & 0.0000 \\
\hline 437 & Textile finishing & 0.0245 & 0.0220 & 0.0550 & 0.0000 & 0.0116 & 0.0167 & 0.0391 & 0.0000 \\
\hline 438 & $\begin{array}{l}\text { Carpets and other textile floor } \\
\text { covering }\end{array}$ & 0.0655 & 0.0273 & 0.0913 & 0.0000 & 0.0762 & 0.0512 & 0.1359 & 0.0000 \\
\hline 439 & Miscellaneous textiles & 0.0458 & 0.0123 & 0.0667 & 0.0304 & 0.0613 & 0.0367 & 0.1417 & 0.0000 \\
\hline 441 & $\begin{array}{l}\text { Leather (tanning and dressing) and } \\
\text { fellmongery }\end{array}$ & 0.0000 & 0.0000 & 0.0000 & 0.0000 & 0.0000 & 0.0000 & 0.0000 & 0.0000 \\
\hline 442 & Leather goods & 0.0014 & 0.0044 & 0.0139 & 0.0000 & 0.0000 & 0.0000 & 0.0000 & 0.0000 \\
\hline 451 & Footwear & 0.0264 & 0.0073 & 0.0368 & 0.0166 & 0.0170 & 0.0232 & 0.0709 & 0.0000 \\
\hline
\end{tabular}




\begin{tabular}{|c|c|c|c|c|c|c|c|c|c|}
\hline \multirow[b]{2}{*}{ sic 1980} & \multirow[b]{2}{*}{ Industry description } & \multicolumn{4}{|c|}{ FDI employment } & \multicolumn{4}{|c|}{ FDI capital } \\
\hline & & Mean & Standard deviation & $\operatorname{Max}$ & Min & Mean & Standard deviation & $\operatorname{Max}$ & Min \\
\hline 453 & Clothing, hats and gloves & 0.0382 & 0.0200 & 0.0883 & 0.0244 & 0.0480 & 0.0408 & 0.1328 & 0.0010 \\
\hline 455 & $\begin{array}{l}\text { Household and other made-up } \\
\text { textiles }\end{array}$ & 0.0243 & 0.0123 & 0.0414 & 0.0000 & 0.0161 & 0.0167 & 0.0400 & 0.0000 \\
\hline 461 & Sawmilling, planing, etc. of wood & 0.0152 & 0.0087 & 0.0260 & 0.0068 & 0.0143 & 0.0108 & 0.0356 & 0.0000 \\
\hline 462 & $\begin{array}{l}\text { Manufacture of semi-finished wood } \\
\text { products. Further treatment of } \\
\text { wood }\end{array}$ & 0.1829 & 0.1197 & 0.3719 & 0.0000 & 0.4071 & 0.2986 & 0.7128 & 0.0000 \\
\hline 463 & Builders' carpentry and joinery & 0.0015 & 0.0025 & 0.0061 & 0.0000 & 0.0006 & 0.0013 & 0.0032 & 0.0000 \\
\hline 464 & Wooden containers & 0.0029 & 0.0093 & 0.0294 & 0.0000 & 0.0048 & 0.0151 & 0.0476 & 0.0000 \\
\hline 465 & $\begin{array}{l}\text { Other wooden articles (except } \\
\text { furniture) }\end{array}$ & 0.0015 & 0.0034 & 0.0099 & 0.0000 & 0.0010 & 0.0033 & 0.0103 & 0.0000 \\
\hline 466 & $\begin{array}{l}\text { Articles of cork and plating } \\
\text { materials, brushes and brooms }\end{array}$ & 0.1745 & 0.0928 & 0.2353 & 0.0000 & 0.1523 & 0.1654 & 0.3810 & 0.0000 \\
\hline 467 & $\begin{array}{l}\text { Wooden and upholstered furniture } \\
\text { and shop and office fittings }\end{array}$ & 0.0200 & 0.0038 & 0.0267 & 0.0142 & 0.0378 & 0.0181 & 0.0686 & 0.0166 \\
\hline 471 & Pulp, paper and board & 0.2006 & 0.0635 & 0.2804 & 0.1424 & 0.2478 & 0.1787 & 0.5782 & 0.0000 \\
\hline 472 & Conversion of paper and board & 0.2018 & 0.0332 & 0.2768 & 0.1682 & 0.2465 & 0.1347 & 0.4869 & 0.0000 \\
\hline 475 & Printing and publishing & 0.1088 & 0.0205 & 0.1399 & 0.0787 & 0.1497 & 0.0798 & 0.3716 & 0.1033 \\
\hline 481 & Rubber products & 0.2022 & 0.1755 & 0.3911 & 0.0000 & 0.2338 & 0.2110 & 0.4799 & 0.0000 \\
\hline 483 & $\begin{array}{l}\text { Retreading and specialised repairing } \\
\text { of rubber tyres }\end{array}$ & 0.1447 & 0.0143 & 0.1737 & 0.1202 & 0.1638 & 0.0305 & 0.2104 & 0.1267 \\
\hline 491 & Jewellery and coins & 0.0057 & 0.0180 & 0.0568 & 0.0000 & 0.0000 & 0.0000 & 0.0000 & 0.0000 \\
\hline 492 & Musical instruments & 0.0000 & 0.0000 & 0.0000 & 0.0000 & 0.0000 & 0.0000 & 0.0000 & 0.0000 \\
\hline 494 & Toys and sports goods & 0.0756 & 0.0420 & 0.1719 & 0.0417 & 0.0946 & 0.0907 & 0.2639 & 0.0000 \\
\hline 495 & $\begin{array}{l}\text { Miscellaneous manufacturing } \\
\text { industries }\end{array}$ & 0.1095 & 0.0317 & 0.1923 & 0.0840 & 0.1999 & 0.1033 & 0.3357 & 0.0000 \\
\hline
\end{tabular}

